\title{
$\alpha$-Internexin Is Structurally and Functionally Associated with the Neurofilament Triplet Proteins in the Mature CNS
}

\author{
Aidong Yuan, ${ }^{1,3}$ Mala V. Rao, ${ }^{1,3}$ Takahiro Sasaki, ${ }^{1}$ Yuanxin Chen, ${ }^{1,2}$ Asok Kumar, ${ }^{1,3}$ Veeranna, ${ }^{1,3}$ Ronald K. H. Liem, ${ }^{5}$ \\ Joel Eyer, ${ }^{6}$ Alan C. Peterson, ${ }^{7}$ Jean-Pierre Julien, ${ }^{8}$ and Ralph A. Nixon ${ }^{1,3,4}$ \\ ${ }^{1}$ Center for Dementia Research and ${ }^{2}$ Department of Medical Physics, Nathan Kline Institute, Orangeburg, New York 10962, Departments of ${ }^{3}$ Psychiatry and \\ ${ }^{4}$ Cell Biology, New York University School of Medicine, New York, New York 10016, ${ }^{5}$ Department of Pathology, College of Physicians and Surgeons, \\ Columbia University, New York, New York 10032, 'aboratoire Neurobiologie et Transgenese, Institut National de la Santé et de la Recherche Médicale, \\ Centre Hospitalier Universitaire, 49033 Angers Cedex, France, ${ }^{7}$ Molecular Oncology Group, McGill University, Royal Victoria Hospital, Montreal, Québec, \\ Canada H3A1A1, and ${ }^{8}$ Centre de Recherche du Centre Hospitalier de l'Université Laval, Département d'anatomie et Physiologie de l'Université Laval, \\ Québec, Québec, Canada G1V 4G2
}

$\alpha$-Internexin, a neuronal intermediate filament protein implicated in neurodegenerative disease, coexists with the neurofilament (NF) triplet proteins (NF-L, NF-M, and NF-H) but has an unknown function. The earlier peak expression of $\alpha$-internexin than the triplet during brain development and its ability to form homopolymers, unlike the triplet, which are obligate heteropolymers, have supported a widely held view that $\alpha$-internexin and neurofilament triplet form separate filament systems. Here, we demonstrate, however, that despite a postnatal decline in expression, $\alpha$-internexin is as abundant as the triplet in the adult CNS and exists in a relatively fixed stoichiometry with these subunits. $\alpha$-Internexin exhibits transport and turnover rates identical to those of triplet proteins in optic axons and colocalizes with NF-M on single neurofilaments by immunogold electron microscopy. $\alpha$-Internexin also coassembles with all three neurofilament proteins into a single network of filaments in quadruple-transfected SW13vim(-) cells. Genetically deleting NF-M alone or together with $\mathrm{NF}-\mathrm{H}$ in mice dramatically reduces $\alpha$-internexin transport and content in axons throughout the CNS. Moreover, deleting $\alpha$-internexin potentiates the effects of NF-M deletion on NF-H and NF-L transport. Finally, overexpressing a NF-H-LacZ fusion protein in mice induces $\alpha$-internexin and neurofilament triplet to aggregate in neuronal perikarya and greatly reduces their transport and content selectively in axons. Our data show that $\alpha$-internexin and the neurofilament proteins are functionally interdependent. The results strongly support the view that $\alpha$-internexin is a fourth subunit of neurofilaments in the adult CNS, providing a basis for its close relationship with neurofilaments in CNS diseases associated with neurofilament accumulation.

Key words: $\alpha$-internexin; neurofilament; intermediate filament; neurofilament inclusion disease; tropical spastic paraparesis; axonal transport; cytoskeleton

\section{Introduction}

Intermediate filament (IF) proteins are a class of tissue-specific proteins, sharing structural properties and the ability to assemble into $10 \mathrm{~nm}$ filaments. As they mature, neurons synthesize distinctive sets of IF proteins that serve varying support and scaffolding roles in axon and dendrite outgrowth, stabilization, and function. At the earliest stage of neuronal development, nestin is expressed in stem cells of the CNS but is suppressed during subsequent development (Lendahl et al., 1990). Vimentin, an IF protein in many mesenchymal cell types, is abundant in most CNS neurons before they differentiate and persists into some mature neurons, where it contributes to neurite formation and extension (Nixon

\footnotetext{
Received Feb. 10, 2006; revised Aug. 15, 2006; accepted Aug. 20, 2006.

This work was supported by National Institute on Aging Grant AG05604 (R.A.N.). We thank Helen Shio (Rockefeller University, New York, NY) for her help with immunoelectron microscopy images.

Correspondence should be addressed to Dr. Aidong Yuan, Center for Dementia Research, Nathan Kline Institute, New York University School of Medicine, 140 Old Orangeburg Road, Orangeburg, NY 10962. E-mail: yuan@nki.rmh.org.

DOI:10.1523/JNEUROSC1.2580-06.2006

Copyright $\odot 2006$ Society for Neuroscience $\quad$ 0270-6474/06/2610006- $14 \$ 15.00 / 0$
}

and Shea, 1992; Perrin et al., 2005). After synaptic connections are established, neurofilaments (NFs) containing the neurofilament "triplets" NF-L (70 kDa), NF-M (150 kDa), and NF-H (200 $\mathrm{kDa}$ ) become the principal constituents of the neuronal IF network.

CNS neurons also contain $\alpha$-internexin, which was initially identified as an IF binding protein (Pachter and Liem, 1985). Subsequently, the structural properties of $\alpha$-internexin and the ability to assemble into filaments by itself or together with either neurofilament proteins or vimentin established $\alpha$-internexin as an IF protein (Kaplan et al., 1990; Ching and Liem, 1993; Steinert et al., 1999). Although its specificity for neurons and abundance in axons led early investigators to suspect that $\alpha$-internexin, like peripherin, may be a subunit of neurofilaments (Portier et al., 1983; Chiu et al., 1989; Kaplan et al., 1990), little evidence has been brought to bear on this possibility (Al-Chalabi and Miller, 2003; Lariviere and Julien, 2004; Liu et al., 2004). Moreover, other studies have supported the view that $\alpha$-internexin forms a separate filament system (Benson et al., 1996; Chien et al., 1996; McGraw et al., 2002). $\alpha$-Internexin can form homopolymers, 
unlike the neurofilament triplets, which are obligate heteropolymers (Ching and Liem, 1993; Cooper and Hausman, 2003). $\alpha$-Internexin gene expression is highest before birth and declines somewhat before expression of the triplet protein sharply rises postnatally (Kaplan et al., 1990). In exceptional cases, such as mature cerebellar granules cells, $\alpha$-internexin is reported to exist in the absence of detectable neurofilament triplet (Chien et al., 1996). In contrast, the concept of the neurofilament as a polymer composed of three subunits continues to be universally accepted and consistently articulated, without exception, in all published works and major reviews on this subject (Perrone Capano et al., 2001; Al-Chalabi and Miller, 2003; Gama Sosa et al., 2003; Garcia et al., 2003; Xia et al., 2003; Cairns et al., 2004a; Lariviere and Julien, 2004; Liu et al., 2004; Lobsiger et al., 2005; Petzold, 2005; Theiss et al., 2005). The physiological roles of $\alpha$-internexin, therefore, remain essentially undefined.

Beyond its important neurobiological implications, understanding the function and relationship of $\alpha$-internexin to neurofilaments takes on additional significance in light of the recent identification of a form of late-onset dementia characterized by inclusions of neuronal IF proteins (Cairns et al., 2003; Josephs et al., 2003). Initially termed "neurofilament inclusion disease," this condition was renamed "neuronal IF inclusion disease" when $\alpha$-internexin was discovered in the pathological inclusions, underscoring the prevailing view that $\alpha$-internexin is not a component of the neurofilament (Cairns et al., 2004a,b,c; Momeni et al., 2005; Mosaheb et al., 2005). $\alpha$-Internexin is also implicated in tropical spastic paraparesis/human T-cell leukemia virus type 1-associated myelopathy (Reddy et al., 1998), a degenerative CNS disorder in which neurofilaments accumulate in giant axonal spheroids (Wu et al., 1993; Liberski et al., 1994; Liberski et al., 1999). Finally, $\alpha$-internexin overexpression causes neurofilament accumulations and motor coordination deficits in transgenic mice (Ching et al., 1999).

Recently, we observed that $\alpha$-internexin is important for NF-M axonal transport when NF-H and NF-L are deleted from mice (Yuan et al., 2003), suggesting that the interaction between these proteins may be functionally significant. To define further the relationship between $\alpha$-internexin and neurofilament triplets, we investigated here the behavior and distribution of $\alpha$-internexin under physiological conditions in vivo and conditions in which neurofilament behaviors were altered by genetically deleting or modifying one or more neuronal IF subunits. Our data identify important new structural and functional relationships between $\alpha$-internexin and neurofilament triplets. Moreover, by applying criteria previously used to establish the triplets as neurofilament subunits as well as new criteria based on novel genetic findings, we obtained strong evidence that $\alpha$-internexin is a subunit of CNS neurofilaments. The studies reconcile previous observations on $\alpha$-internexin, including the similar behaviors of $\alpha$-internexin and neurofilament triplets observed in pathological states.

\section{Materials and Methods}

Generation of knock-out animals. Adult male or female mice of the C57BL/6J strain, 3-12 months of age at the time of injection or when they were killed, were used in all experiments. Mice were housed at $23^{\circ} \mathrm{C}$ on a 12 h light/dark cycle and were maintained on Lab Chow (Purina Mills, Gray Summit, MO) supplied ad libitum. Production of NF-H knock-out (hko) (Rao et al., 1998), NF-M knock-out (mko) (Jacomy et al., 1999), $\alpha$-internexin knock-out ( $\alpha$-iko) (Levavasseur et al., 1999), and NFHLacZ mice (Eyer and Peterson, 1994) has been described previously. $\alpha$-Internexin and NF-H double knock-outs ( $\alpha$-ih-dko) were generated by cross breeding $\alpha$-iko with hko. $\alpha$-Internexin and NF-M double knock-outs ( $\alpha$-im-dko) were generated by cross breeding $\alpha$-iko with mko. NF-H and NF-M double knock-outs (hm-dko) were generated by cross breeding hko with mko mice.

Southern blot screening of knock-out mice was performed as below. One-half-centimeter tails cut from the tip of offspring of heterozygous/ heterozygous mating were incubated overnight at $55^{\circ} \mathrm{C}$ with $10 \mu \mathrm{l}$ of 20 $\mathrm{mg} / \mathrm{ml}$ proteinase $\mathrm{K}$ in $0.5 \mathrm{ml}$ of $50 \mathrm{~mm}$ Tris buffer, $\mathrm{pH} 7.4,100 \mathrm{~mm}$ EDTA, pH 8, $400 \mathrm{~mm} \mathrm{NaCl}$, and $0.5 \%$ SDS. Subsequently, $150 \mu \mathrm{l}$ of $7 \mathrm{M}$ $\mathrm{NaCl}$ was added to the digested tails and vigorously shaken $30 \mathrm{~s}$ and centrifuged at $10,000 \times g$ for $5 \mathrm{~min}$ before adding $0.5 \mathrm{ml}$ of $100 \%$ ethanol per $0.5 \mathrm{ml}$ of supernatant and centrifuging for $5 \mathrm{~min}$ in $4^{\circ} \mathrm{C}$ to pellet DNA. The DNA was washed twice with $0.5 \mathrm{ml}$ of $70 \%$ ethanol and airdried before incubating in $100 \mu \mathrm{l}$ of $10 \mathrm{~mm}$ Tris, $\mathrm{pH} 8,1 \mathrm{~mm}$ EDTA at $55^{\circ} \mathrm{C}$ for $20 \mathrm{~min}$ and then vortexing for $5 \mathrm{~s}$ to fully suspend the DNA. The purified genomic DNA was digested overnight at $37^{\circ} \mathrm{C}$ with HindIII for $\mathrm{NF}-\mathrm{H}, \mathrm{BamHI}$ for NF-M, or EcoRI for $\alpha$-internexin and separated on a $0.8 \%$ agarose gel, denatured with $0.5 \mathrm{M} \mathrm{NaOH}$ and $1.5 \mathrm{M} \mathrm{NaCl}$ for $30 \mathrm{~min}$, and transferred to Hybond N+ filters (Amersham Bioscience, Buckinghamshire, UK) overnight. The membrane was then neutralized with 1.5 $\mathrm{M} \mathrm{NaCl}$ and $0.5 \mathrm{M}$ Tris, $\mathrm{pH}$ 7, for $15 \mathrm{~min}$ prehybridized at $65^{\circ} \mathrm{C}$ for $1 \mathrm{~h}$ in $200 \mathrm{ml}$ of Church and Gilbert hybridization solution (containing $100 \mathrm{ml}$ of $1 \mathrm{~m}$ phosphate buffer, $0.4 \mathrm{ml}$ of $0.5 \mathrm{~m}$ EDTA, $\mathrm{pH} 8,2 \mathrm{~g}$ of BSA, $14 \mathrm{~g}$ of SDS) and hybridized overnight at $65^{\circ} \mathrm{C}$ with labeled probe. The membrane was then washed once at room temperature for $10 \mathrm{~min}$ with $17.53 \% \mathrm{NaCl}, 8.82 \%$ sodium citrate, $\mathrm{pH} 7.4$, and washed twice at $60^{\circ} \mathrm{C}$ for 30 min with $1.753 \% \mathrm{NaCl}, 0.882 \%$ sodium citrate, $\mathrm{pH} 7.4$, containing $0.5 \%$ SDS before being exposed to $\mathrm{x}$-ray film at $-80^{\circ} \mathrm{C}$ overnight.

Isotope injections. Adult mice were anesthetized with 13-20 $\mu \mathrm{l} / \mathrm{g}$ body weight of Avertin (0.5 g of tribromoethanol and $0.25 \mathrm{~g}$ of 2-methyl-2butanol in $39.5 \mathrm{ml}$ of distilled water) and received $0.30 \mu \mathrm{l}$ of phosphatebuffered normal saline, $\mathrm{pH} 7.4$, which contained $50 \mu \mathrm{Ci}$ L- $\left[{ }^{35} \mathrm{~S}\right]$ methionine (specific activity $1175 \mathrm{Ci} / \mathrm{mmol}$ ) or $25 \mu \mathrm{Ci} \mathrm{L}-[2,3-$ ${ }^{3} \mathrm{H}$ ]Proline (specific activity $30-50 \mathrm{Ci} / \mathrm{mmol}$ ) purchased from PerkinElmer (Boston, MA). Injections were made into the vitreous of each eye with a glass micropipette $(70-100 \mu \mathrm{m})$ apparatus (Nixon and Logvinenko, 1986).

Axonal transport studies. The retinal ganglion cells of adult hko, mko, $\alpha$-ih-dko, $\alpha$-im-dko, or hm-dko mice and their corresponding wild-type controls were radiolabeled by intravitreal injection. The primary optic pathway consists of the optic nerve, the optic chiasm, and part of the optic tract extending to, but not including, terminals in the lateral geniculate nucleus. One, $7,14,21$, or up to $150 \mathrm{~d}$ after isotope injection, optic pathways from groups of three animals were dissected and cut into eight consecutive $1 \mathrm{~mm}$ segments on a micrometer slide on dry ice. Tritonsoluble and Triton-insoluble preparations from each segment were subjected to SDS-PAGE, electrotransfer of proteins, phosphoimaging, and autoradiography (Yuan et al., 2003, 2006). Glial cells of the optic nerve were radiolabeled selectively by incubating optic axons in vitro with ${ }^{35} \mathrm{~S}$ methionine (Nixon, 1982) and compared with optic axons labeled by invitreal injection of ${ }^{35} \mathrm{~S}$-methionine. These experimental protocols were approved by the New York University and Nathan Kline Institute Institutional Animal Care and Use Committees under the guidelines of the Institutional Animal Care and Use Committee of the United States.

Tissue preparation, SDS-PAGE, and immunoblot analysis. Each optic pathway segment pooled from three mice was homogenized in $125 \mu \mathrm{l}$ of cytoskeleton extraction buffer $(50 \mathrm{~mm}$ Tris- $\mathrm{HCl}, \mathrm{pH} 6.8,1 \%$ Triton $\mathrm{X}-1000,10 \%$ glycerol, $0.15 \mathrm{~m} \mathrm{NaCl}, 2 \mathrm{~mm}$ EDTA, $2 \mathrm{~mm}$ PMSF, $50 \mu \mathrm{g} / \mathrm{ml}$ leupeptin, $2.5 \mu \mathrm{g} / \mathrm{ml}$ aprotinin). The homogenate was centrifuged at $15,000 \times g$ for $30 \mathrm{~min}$ at $4^{\circ} \mathrm{C}$ to isolate Triton-soluble and Tritoninsoluble particulate fractions. Total protein extracts from nervous tissues were homogenized in buffer containing $25 \mathrm{~mm}$ sodium phosphate, pH 7.2, 5 mm EGTA, 1\% SDS, and 1 mm phenylmethylsulfonyl fluoride, and protein concentration was measured with the bicinchonic acid assay (Sigma-Aldrich, St. Louis, MO). One-dimensional (1D) SDS-PAGE was performed using $320 \mathrm{~mm}$ slab gels containing $5-15 \%$ linear polyacrylamide gradients. Two-dimensional (2D) gel electrophoresis was performed as described previously (Yuan et al., 1997, 2000). PAGEseparated proteins were transferred to nitrocellulose membranes and immunostained using an alkaline phosphatase-conjugated indirect anti- 
body procedure. The distribution of $\left[{ }^{35} \mathrm{~S}\right]$ methionine-labeled proteins was visualized by autoradiography or phosphoimaging. The radioactivity associated with each of the NF subunits was determined by phosphoimaging or computer-assisted densitometry of autoradiographs. Antibodies used were monoclonal antibodies (mAbs) to NF-L (NR4), NF-M (NN18), NF-H (N52) (Sigma), and $\alpha$-internexin (MAB5224; Chemicon), respectively.

Immunoelectron microscopy. Adult mice were anesthetized with halothane gas, and the tissue was fixed through intracardial perfusion with $0.9 \%$ sodium chloride, optic pathways removed and placed into fresh cold $4 \%$ paraformaldehyde in PBS. The nerve was cut into short cylinders. For Lowicryl K4M, some of the nerve pieces were rinsed with $0.1 \mathrm{M}$ cacodylate buffer, $\mathrm{pH} 7.4$, treated with graded alcohol series and embedded in hydrophilic resin Lowicryl K4M (Electron Microscopy Sciences, Fort Washington, PA). The samples were UV light polymerized in the freezer for $3 \mathrm{~d}$. The sections were incubated with rabbit anti-NF-M (prepared using purified mouse NF-M proteins as antigen) and mouse anti- $\alpha$-internexin (MAB5224; Chemicon) mixture (1:100/1:2) and probed with goat anti-rabbit IgG and/or goat antimouse IgG conjugated to $5 \mathrm{~nm}$ and $10 \mathrm{~nm}$ gold beads (Amersham Biosciences, Arlington Heights, IL). The grids were stained with uranyl acetate before viewing in Tecnai G2 Spirit electron microscope (FEI Company, Hillsboro, OR) equipped with Ultrascan 895 CCD camera (Gatan, Pleasanton, CA). For ultrathin cryosections, some of the nerve pieces were treated with $2.3 \mathrm{~m}$ sucrose and frozen in liquid nitrogen. Cryo-ultrathin sections were cut using a Leica EM FC6 cryo-ultramicrotome. Sections were treated with $10 \%$ FCS in PBS and incubated with rabbit anti-NF-M and mouse anti- $\alpha$ internexin mixture (1:200/1:5). The grids were incubated with goat anti-rabbit IgG conjugated to $10 \mathrm{~nm}$ or $5 \mathrm{~nm}$ gold particles and goat antimouse IgG conjugated to $10 \mathrm{~nm}$ or $5 \mathrm{~nm}$ gold particles. The immunolabeling procedure was done by the Tokuyasu method (Griffiths et al., 1983; Tokuyasu, 1986). The grids were photographed on a JEOL $100 \times$ electron microscope operated at $80 \mathrm{kV}$.

Immunocytochemistry. Adult mice were anesthetized with halothane gas, and the tissue was fixed through intracardial perfusion with $4 \%$ paraformaldehyde, $0.2 \%$ glutaraldehyde in 0.1 м PBS, $\mathrm{pH} 7.4$, at room temperature. The brain was dissected, and $40-\mu \mathrm{m}$-thick vibratome sections were processed for immunocytochemistry using antibodies to $\alpha$-internexin (MAB5224, AB5334; Chemicon) and N52 (anti-NF-H; Sigma-Aldrich), SMI31, and SMI33 to neurofilament proteins. The sections were counterstained with diluted cresyl violet. Several sections were processed in tandem in the absence of primary antibody, which served as controls.

Immunofluorescence of SW13vim(-) cells. Transfection and immunofluorescence staining of SW13vim(-) cells are performed as described previously (Sasaki et al., 2006). The ex-

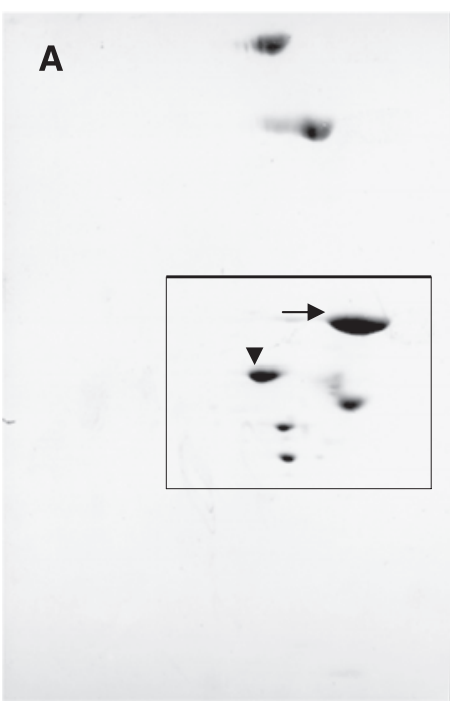

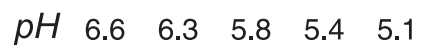

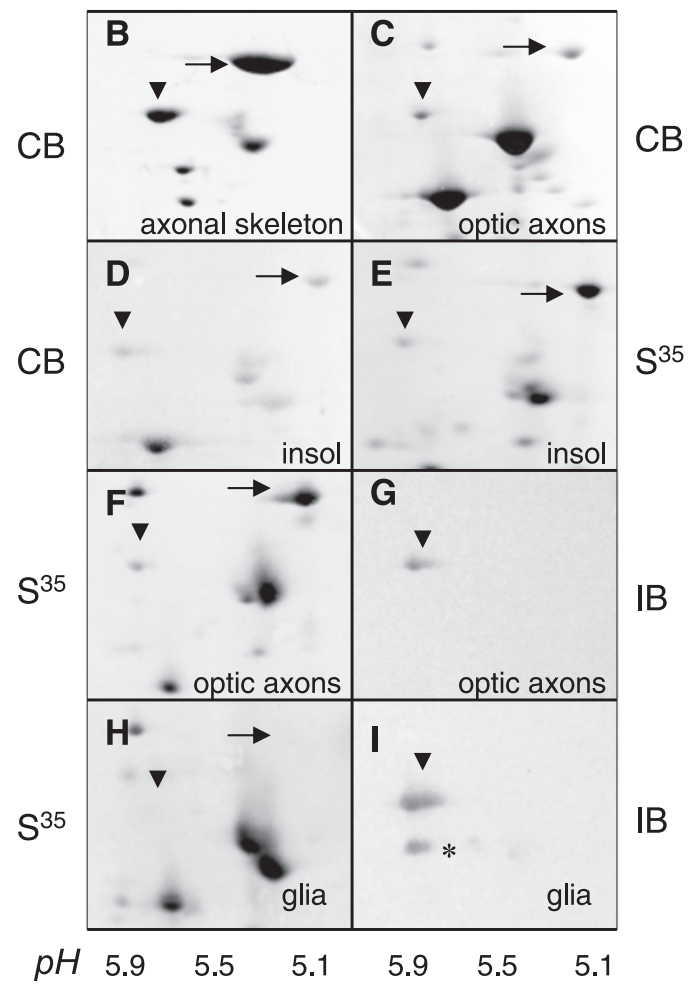

J
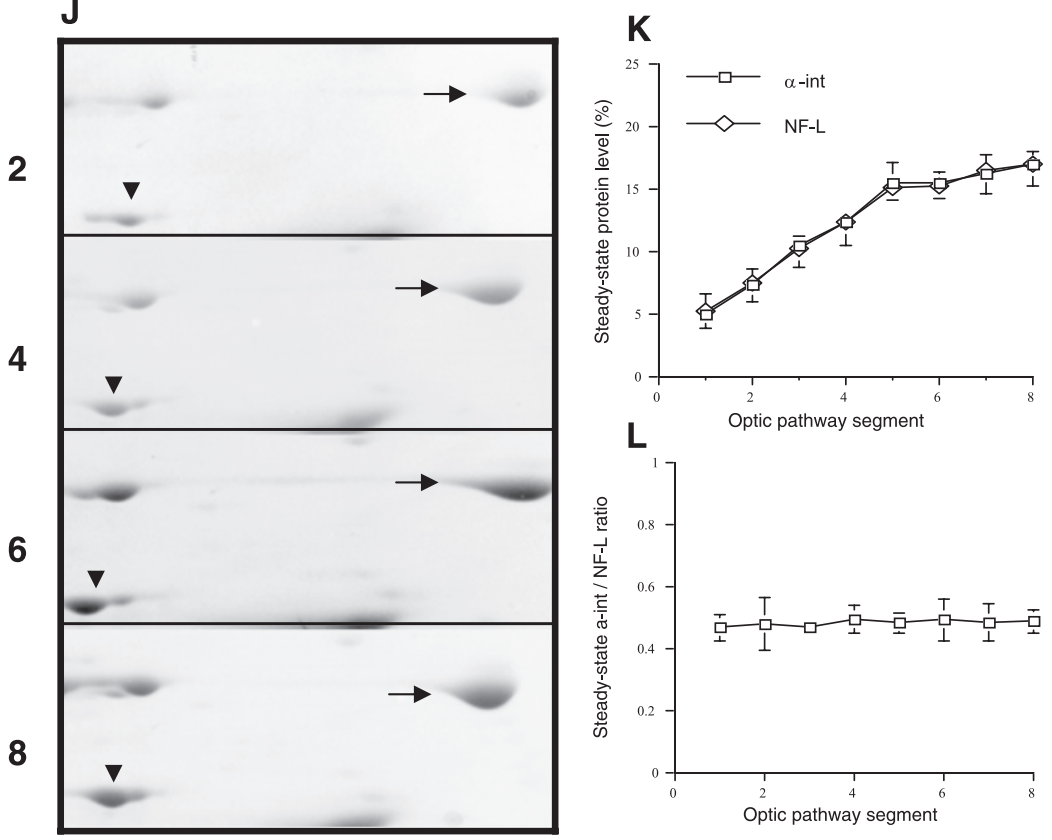

Figure 1. Immunologic identification of $\alpha$-internexin in Triton-soluble and Triton-insoluble fractions of optic axon separated by two-dimensional gel electrophoresis. $\boldsymbol{A}, \boldsymbol{B}$, Only the relevant portions of the $2 \mathrm{D}$ gels are depicted. $\boldsymbol{C}-\boldsymbol{E}$, In mouse axons, $\alpha$-internexin is a $58 \mathrm{kDa}$ protein with an isolectric point of 5.5-5.6 (C) and is exclusively Triton-insoluble and heavily radiolabeled in optic axons after intravitreal injection of ${ }^{35} S$-methionine $(\boldsymbol{D}, \boldsymbol{E}) . \boldsymbol{F}-\boldsymbol{I}, \alpha$-Internexin and its radiolabeled counterpart are detected in axons $(\boldsymbol{F}, \boldsymbol{G})$ but not in glial cells of optic nerves $(\boldsymbol{H}, \boldsymbol{I})$ by immunoblot analyses after selectively labeling axons and glia (see Materials and Methods). $\boldsymbol{B}$ and $\boldsymbol{C}$ are Coomassie blue-stained gels of axonal cytoskeleton (prepared from mouse spinal cord) and optic axons, respectively. $\boldsymbol{D}$ and $\boldsymbol{E}$ are Coomassie blue-stained gel of Triton-insoluble fraction and its corresponding autoradiograph, respectively. $\boldsymbol{F}$ and $\boldsymbol{H}$ are autoradiographs of optic axons and glial cells, respectively; $\boldsymbol{G}$ and $\boldsymbol{I}$ are their corresponding immunoblots stained for $\alpha$-internexin, respectively. J- $L$ show $\alpha$-internexin and NF-L ratio along optic pathway. $K, L, C$ Comassiestained 2D gels of Triton-insoluble fractions from consecutive $1 \mathrm{~mm}$ segments of the optic nerve and tract demonstrate that $\alpha$-internexin and NF-L show the same proximal to distal increase (approximate threefold) $(\boldsymbol{K})$ and maintain a constant ratio $(\sim 50 \%)$ along optic pathway $(\boldsymbol{L})$. The even numbers in $J$ represent nerve segment numbers. $\alpha$-Internexin and NF-L are indicated by an arrowhead and arrow, respectively. The asterisk in $I$ is a degradation product of $\alpha$-internexin. CB, Coomassie blue; $\mathrm{S} 35$, autoradiograph; IB, immunoblot. 
A

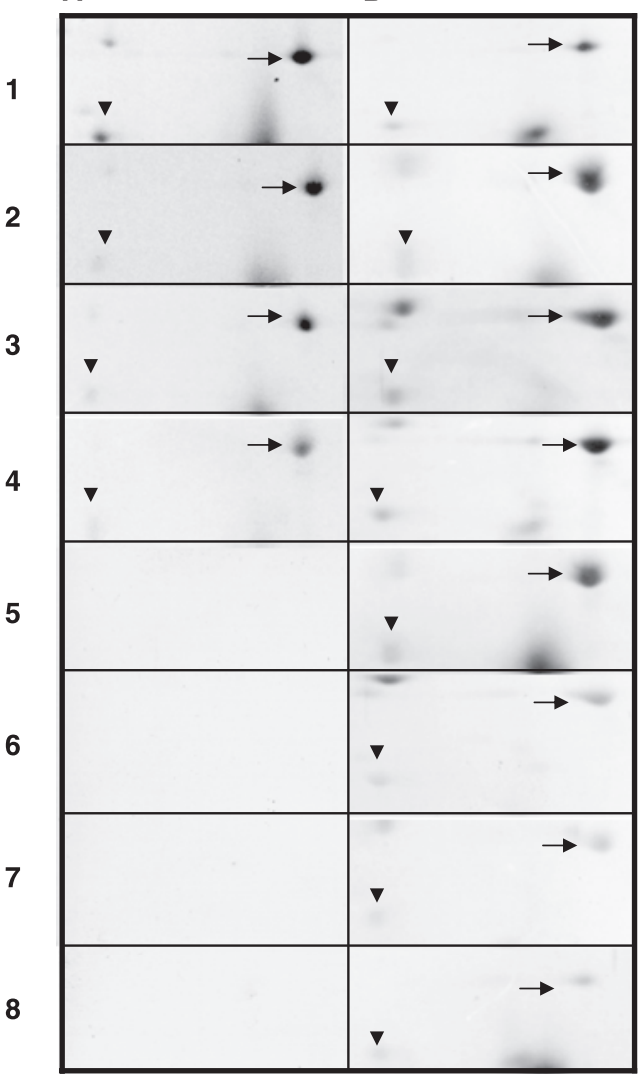

C
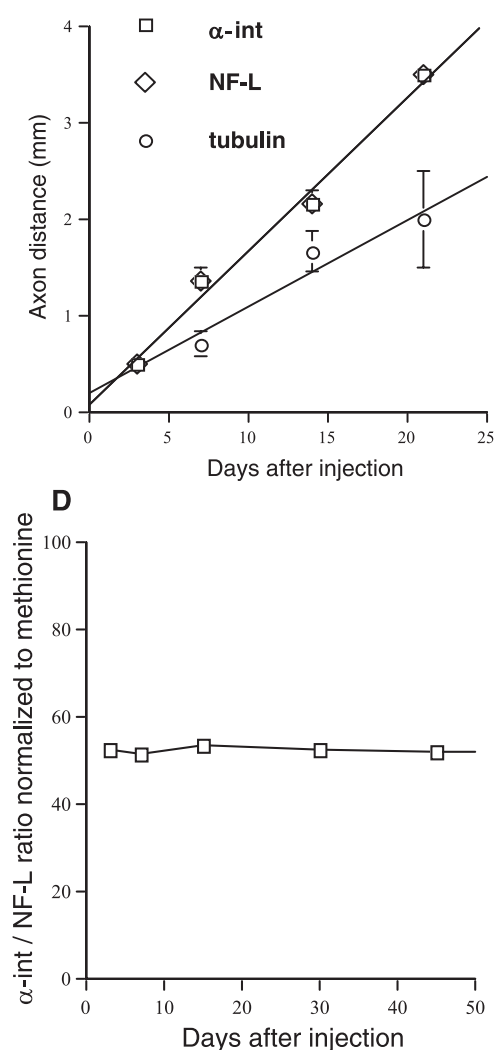

Figure 2. $\quad \alpha$-Internexin (arrowhead) and NF-L (arrow) have identical axonal transport rates and maintain a constant ratio during transport. $\boldsymbol{A}, \boldsymbol{B}, 2 \mathrm{D}$ PAGE analysis of consecutive $1 \mathrm{~mm}$ segments of the optic nerve and tract were performed on mice at intervals 3-45 dafter injecting ${ }^{35} S$-methionine $(\boldsymbol{A}, 3 \mathrm{~d} ; \boldsymbol{B}, 15 \mathrm{~d})$. C, Regression analysis of replicate series of gels indicated rates of movement of $0.171 \pm 0.048 \mathrm{~mm} / \mathrm{d}$ (mean \pm SD; $n=49)$ for $\alpha$-internexin and NF-L and $0.105 \pm 0.051 \mathrm{~mm} / \mathrm{d}$ (mean \pm SD; $n=$ 49) for Triton-soluble tubulin. $\boldsymbol{D}$, The ratio of labeled $\alpha$-internexin to labeled NF-L was constant during intervals $3-45 \mathrm{~d}$ after isotope injection.

pression plasmid of mouse NF-L, NF-M, and NF-H were constructed by cloning into pcDNA3.1. The expression plasmid of rat $\alpha$-internexin (pRSV- $\alpha$ ) was used as described previously (Ching and Liem, 1993). NF-L was probed with rabbit polyclonal antibody NA1214 (500-fold dilution; Affiniti, Nottingham, UK). NF-M was probed with mouse monoclonal antibody NN18 (500-dilution; Sigma-Aldrich) or antiNF-M rabbit polyclonal antibody (200-dilution) prepared using purified mouse NF-M proteins as antigen. NF-H was probed with mouse monoclonal antibody N52 (2000-fold dilution) or anti-NF-H rabbit polyclonal antibody raised against the COOH-terminal 12 aa of mouse NF-H (2000fold dilution) (Xu et al., 1993), and rat $\alpha$-internexin was probed with anti- $\alpha$-internexin mouse monoclonal antibody MAB5224 (200-fold dilution). Images were observed under an LSM 510 laser-scanning confocal microscope (Zeiss, Oberkochen, Germany).

\section{Results}

Stable stoichiometry of $\boldsymbol{\alpha}$-internexin and NF-L in axonal neurofilaments

In mouse spinal cord and optic axons, $\alpha$-internexin was identified on two-dimensional SDS gels as a $58-59 \mathrm{kDa}$ protein with an isolectric point of 5.5-5.6 (Fig. 1A-C), which was exclusively Triton-insoluble and strongly radiolabeled in optic axons after intravitreal injection of ${ }^{35} S$-methionine in vivo (Fig. $1 D, E$ ). The $\alpha$-internexin protein and its radiolabeled counterpart after intravitreal ${ }^{35} S$-methionine administration were recognized by anti$\alpha$-internexin antibody on immunoblot (Fig. $1 F, G$ ), but radiolabeled $\alpha$-internexin was not detected after labeling glial cells of the optic nerve in vitro (Fig. $1 H, I$ ). $\alpha$-Internexin was present in optic axons in amounts comparable with other neurofilament subunits (Fig. 1). Neurofilaments increase in number proximally to distally along optic axons (Nixon and Logvinenko, 1986). Coomassie-stained gels demonstrated that $\alpha$-internexin and NF-L display the same increase in content from the proximal to the distal end of optic axons, maintaining a constant ratio (Fig. $1 J-L)$ (mean \pm SD; $n=4)$. This ratio does not change significantly in optic nerves of mice from 3-36 months of age (data not shown).

\section{$\alpha$-Internexin and NF-L have identical rates of axonal transport and turnover within axons}

One-dimensional gel electrophoresis analyses have shown that $\alpha$-internexin is transported in the slow component "a" of axonal transport in rat optic axons (Kaplan et al., 1990). To detail further the transport of $\alpha$-internexin in relation to that of neurofilament triplets, we performed both 1D and 2D PAGE analysis of transport along consecutive $1 \mathrm{~mm}$ segments of the optic nerve and tract at intervals 3-150 d after injecting mice intravitreally with ${ }^{35} S$ methionine or ${ }^{3} \mathrm{H}$-proline (Fig. 2). Regression analysis of replicate series of these gels indicated that the rates of movement of $\alpha$-internexin and NF-L are identical $(0.171 \pm 0.048 \mathrm{~mm} / \mathrm{d}$; mean $\pm \mathrm{SD} ; n=$ 49) (Fig. 2C). Triton-soluble tubulin, although also in slow component a of axonal transport, was consistently transported more slowly than neurofilaments $(0.105 \pm$ $0.051 \mathrm{~mm} / \mathrm{d} ;$ mean $\pm \mathrm{SD} ; n=49)$. The ratio of newly synthesized $\alpha$-internexin to labeled NF-L remained constant, indicating similar turnover rates within optic axons for these two proteins. The calculated proportions of $\alpha$-internexin relative to NF-L corresponded well to the 1:2 ratio of $\alpha$-internexin and NF-L in isolated neurofilaments during intervals $3-150 \mathrm{~d}$ after isotope injection (51.7-53.6\%; when normalized to methionine content, 4 in $\alpha$-internexin and 11 in NF-L) (Fig. 2D).

\section{Ultrastructural colocalization of $\alpha$-internexin and NF-M on the same neurofilament in optic axons}

To determine whether $\alpha$-internexin and NF-M coexist on the same filament system, we performed ultrastructural colocalization studies of these two proteins in mouse optic axons using multiple combinations of $\alpha$-internexin and NF-M antibodies and double-immunogold labeling. Thin sections of paraformaldehyde-fixed optic nerve were incubated with mouse anti- $\alpha$-internexin monoclonal antibody and rabbit anti-NF-M polyclonal antibody and then stained with goat anti-mouse and anti-rabbit IgG conjugated with $10 \mathrm{~nm}$ and $5 \mathrm{~nm}$ gold particles, respectively. Anti- $\alpha$-internexin antibody alone decorated most $10 \mathrm{~nm}$ filaments in the axon from normal mice (Fig. $3 A, C$ ), and the specificity of this interaction was confirmed by the absence of labeling in $\alpha$-internexin knock-out animals (Fig. 3B). When both rabbit anti-NF-M and mouse anti- $\alpha$-internexin antibodies were incubated with the sections, immunogold associated with NF-M 
and $\alpha$-internexin decorated the same $10 \mathrm{~nm}$ filaments (Fig. $3 D, E)$. The specificity of the immunogold labeling was also confirmed by staining without primary antibodies.

\section{$\alpha$-Internexin coassembles with all three neurofilament proteins into a single filamentous network}

Previous studies have shown that $\alpha$-internexin can coassemble with each of the neurofilament triplet proteins in doubletransfected SW13vim $(-)$ cells to form filaments. However, when all four proteins are present in the same cell at the same time, it is not known whether or not $\alpha$-internexin self-assembles into its own separate filamentous network or coassembles with all three neurofilament proteins into a single filamentous network. SW13vim(-) cells lacking cytoplasmic intermediate filaments were quadruple-transfected with constructs that expressed $\alpha$-internexin, NF-L, NF-M, and NF-H and were immunostained with mouse monoclonal antibodies to $\alpha$-internexin or NF-M or NF-H and rabbit polyclonal antibodies to NF-L, NF-M, and NF-H. Double immunofluorescence analyses with pairs of antibodies confirmed that all four proteins coassembled into a single network of filaments (Fig. 4).

\section{NF-M deletion accelerates the transport rate of $\alpha$-internexin,} NF-L, and NF-H and reduces their levels

Having previously showed that in the absence of NF-L, $\alpha$-internexin is required for efficient transport of NF-M (Yuan et al., 2003), we examined here how NF-M deletion affects $\alpha$-internexin levels and transport in optic axons. Mouse genomic DNA screening confirmed targeted disruption of NF-M (Fig. $5 A, B)$ in homozygous mice, and Western blot analysis confirmed the absence of NF-M protein in mko mice (Fig. 5D). In the absence of NF-M, the levels of $\alpha$-internexin, NF-H, and NF-L proteins by quantitative immunoblotting were decreased to $54 \pm 8 \%$ (Fig. 5C), $33 \pm 8 \%$ (Fig. $5 E$ ), and $22 \pm 3 \%$ (Fig. $5 F$ ), respectively, of the corresponding levels in control mice. The NF-M mutation causes different reduction of $\alpha$-internexin, NF-L, and NF-H. This may indicate that NF-M partners differently with $\alpha$-internexin and NF-L. The change of NF-H may be secondary to the reduction of other subunits. We determined slow axonal transport by injecting those two groups of mice with ${ }^{35} S$-methionine intravitreally and after injection analyzed by PAGE the radiolabeled proteins in cytoskeleton and Triton-soluble fractions from consecutive $1 \mathrm{~mm}$ segments of the optic pathways. The transport of $\alpha$-internexin, NF-H, and NF-L, but not other cytoskeletal proteins, was markedly accelerated in optic axons from mko mice $7 \mathrm{~d}$ after injection (Fig. 5G-I). Based on comparisons of the peaks of radiolabeled proteins, $\alpha$-internexin, NF-H, and NF-L exhibited the same fivefold acceleration of average transport rate in mice lacking NF-M $(1.07 \mathrm{~mm} / \mathrm{d})$ compared with controls $(0.21 \mathrm{~mm} / \mathrm{d})$ (Fig. 5). Similar results were obtained at $3 \mathrm{~d}$ after injection (data not shown).

\section{Deletion of NF-H and NF-M markedly reduces axonal transport and levels of $\boldsymbol{\alpha}$-internexin and NF-L}

We next examined how deleting NF-H in the absence of NF-M influences the levels and transport of $\alpha$-internexin. NF-H and NF-M double knock-out mice were generated, verified by genomic DNA screening of homozygous mice for targeted disruption of NF-H (Fig. $6 A, B$ ) and NF-M (Fig. 6C,D). As expected, NF-H and NF-M protein were absent (Fig. $6 E, F)$ in hm-dko mice, whereas the steady-state level of $\alpha$-internexin was decreased to below $10 \%$ of wild-type levels (Fig. 6G). As shown in Figure 5, transport of radiolabeled $\alpha$-internexin in wild-type
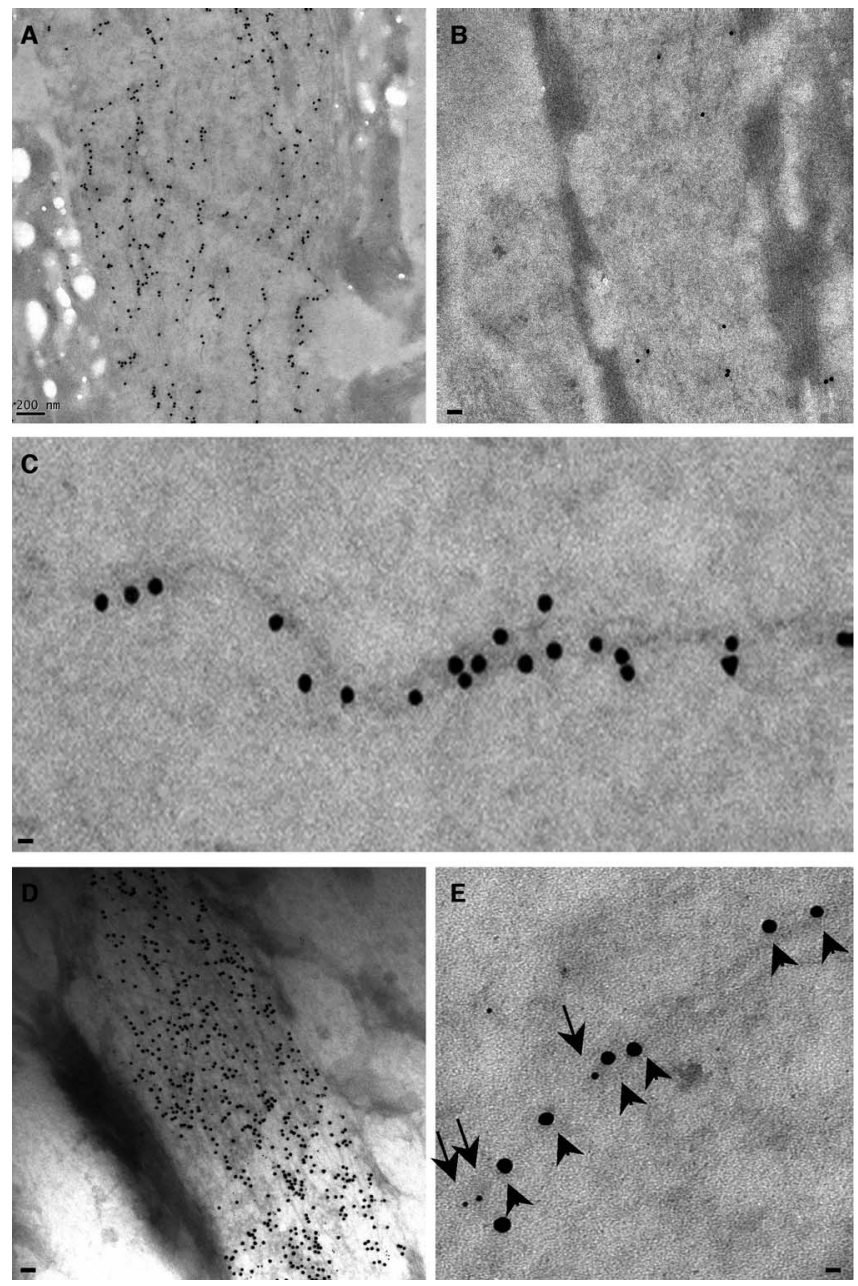

Figure 3. Ultrastructural colocalization of $\alpha$-internexin and NF-M on the same neurofilament in optic nerve. Paraformaldehyde-fixed samples were incubated with mouse anti- $\alpha$ internexin and rabbit anti-NF-M mixture (1:5/1:200) and probed with goat anti-mouse IgG and/or goat anti-rabbit $\lg G$ conjugated to $10 \mathrm{~nm}$ and $5 \mathrm{~nm}$ gold beads. $\boldsymbol{A}, \boldsymbol{B}$, As expected, for the immunodetection of $\alpha$-internexin in normal mice $(\boldsymbol{A})$, large numbers of $10 \mathrm{~nm}$ gold particles are aligned with most $10 \mathrm{~nm}$ filaments in the axon, and negligible numbers are detected in $\alpha$-internexin knock-out mice (B). C, Decoration of a single filament by $10 \mathrm{~nm}$ gold particles conjugated to anti- $\alpha$-internexin antibody. $\boldsymbol{D}$, Linear arrays of two sizes of gold particles ( $10 \mathrm{~nm}$ for $\alpha$-internexin and $5 \mathrm{~nm}$ for NFM) decorate most $10 \mathrm{~nm}$ filaments in the axon. $\boldsymbol{E}$, Higher magnification shows that gold particles of two sizes overlie a single filament in the background. Arrowheads point to $10 \mathrm{~nm}$ particles ( $\alpha$-internexin), and arrows point to $5 \mathrm{~nm}$ particles (NF-M). Scale bars: $\boldsymbol{A}, \boldsymbol{B}, \boldsymbol{D}, 200 \mathrm{~nm} ; \boldsymbol{C}, \boldsymbol{E}, 10 \mathrm{~nm}$.

mice was readily seen on both one-dimensional (Fig. $6 H$ ) and two-dimensional gels (Fig. $6 \mathrm{~J}$ ), whereas $<10 \%$ of the newly synthesized $\alpha$-internexin protein was detected in hm-dko optic axons (Fig. $6 I, K$ ). Because the radiolabeled and steady-state levels of $\alpha$-internexin and NF-L in axons of hm-dko are greatly reduced compared with controls, their transport into axons after synthesis decreased, which was also evidenced through their perikaryal accumulation by immunocytochemistry (Fig. 7N) (our unpublished data).

\section{Genetically inducing loss of neurofilaments depletes} $\alpha$-internexin in axons throughout the CNS

Using $\alpha$-internexin monoclonal antibody MAB5224, we observed that $\alpha$-internexin distributes widely in the brain, as shown in Figure 7. When we deleted NF-M and NF-H in mice (Fig. $7 A, B), \alpha$-internexin was dramatically reduced in axons across 

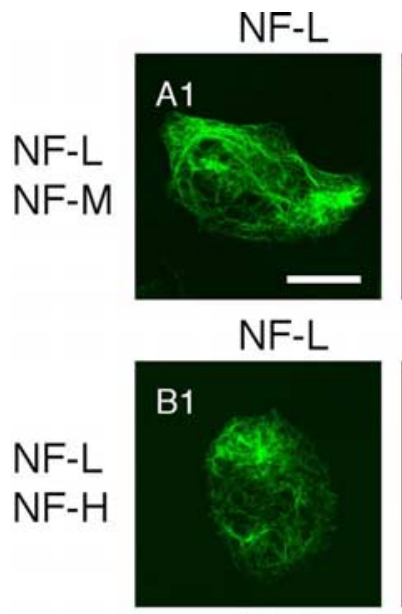

NF-L
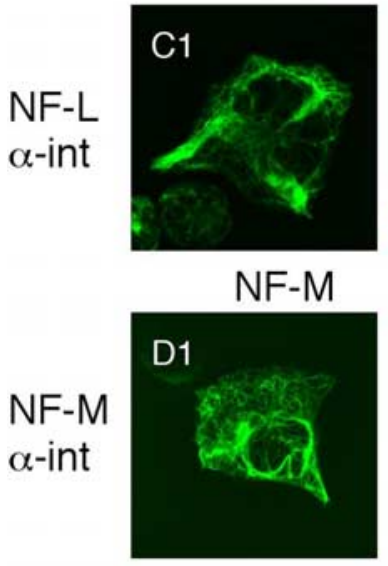

NF-H

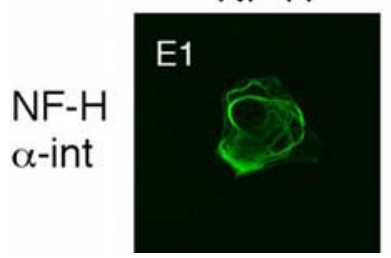

NF-M

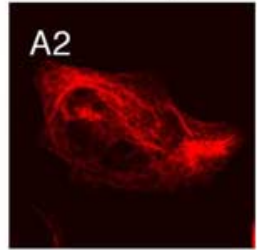

NF-H

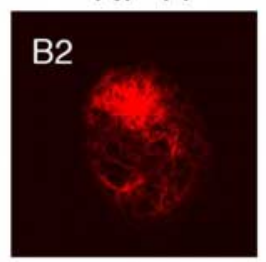

$\alpha$-int

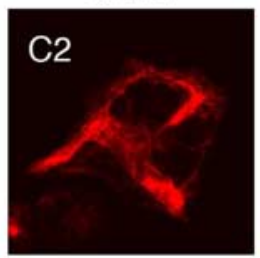

$\alpha$-int

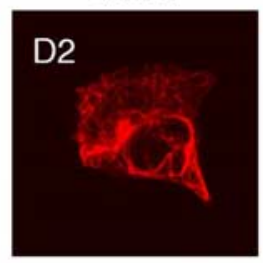

$\alpha$-int

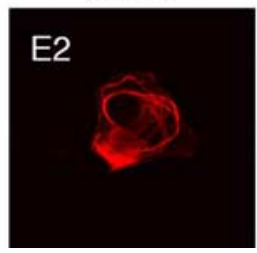

Merge

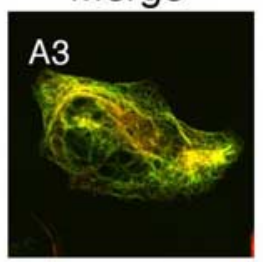

Merge

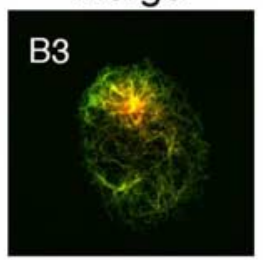

Merge

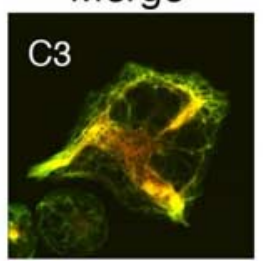

Merge

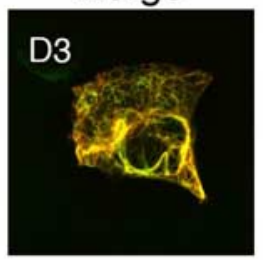

Merge

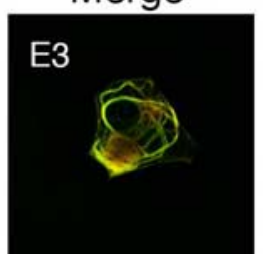

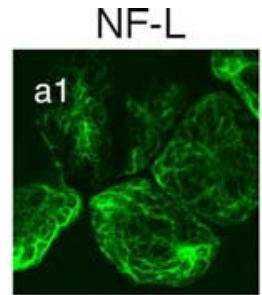

NF-L

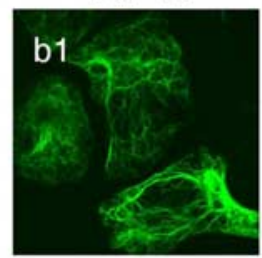

NF-L

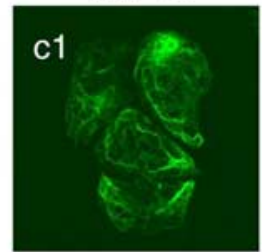

NF-M

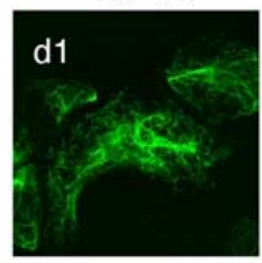

$\mathrm{NF}-\mathrm{H}$

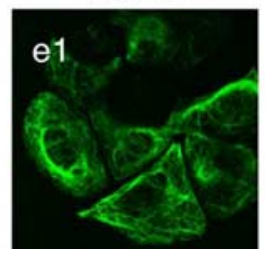

NF-M

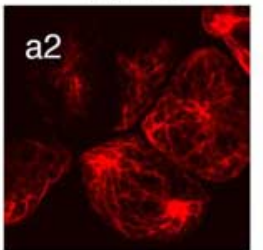

NF-H

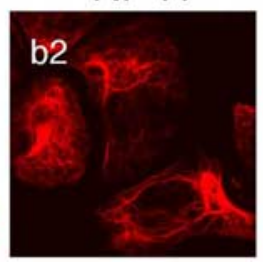

$\alpha$-int

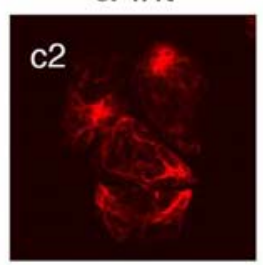

$\alpha$-int

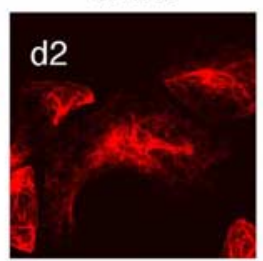

$\alpha$-int

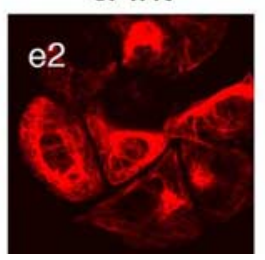

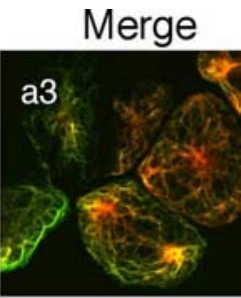

Merge

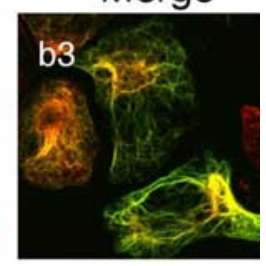

Merge

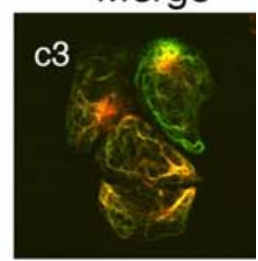

Merge

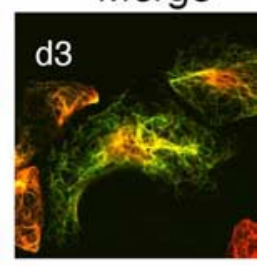

Merge

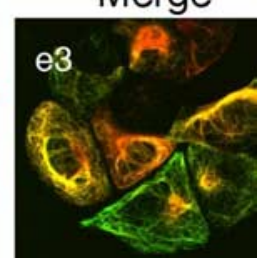

Figure 4. Coassembly of $\alpha$-internexin with all three neurofilament proteins into single filament network. SW13vim(-) cells were quadruple-transfected with constructs that expressed $\alpha$-internexin, NF-L, NF-M, and NF-H and were immunostained with pairs of antibodies. Each set of three panels across represents the single immunolabels and the merged double label (yellow indicating colocalization) for the following pairs of antibodies: $\mathbf{A 1} \mathbf{- 3}$ and $\boldsymbol{a 1}-\mathbf{3}$, rabbit polyclonal antibodies (pAb) to NF-Land mouse monoclonal antibodies (mAb) to NF-M; B1-3 and b1-3, rabbit pAb to NF-L and mouse mAb to NF-H; $\mathbf{C 1 - 3}$ and $\mathbf{c 1 - 3}$, rabbit pAb to NF-L and mouse mAb to $\alpha$-internexin; D1-3 and $\boldsymbol{d 1}$-3, rabbit pAb to NF-M and mouse mAb to $\alpha$-internexin; E1-3 and $\boldsymbol{e} 1$-3, rabbit pAb to NF-H and mouse mAb to $\alpha$-internexin. Scale bar, $20 \mu \mathrm{m}$.

every brain region, including corpus callosum (Fig. 7C,D), hippocampus (Fig. $7 E, F$ ), frontal cortex (Fig. $7 G, H$ ), spinal cord (Fig. $7 I, J$ ), and cerebellum (Fig. $7 K, L$ ). In contrast to the $\alpha$-internexin depletion in neurites, perikarya in hm-dko mice displayed somewhat increased $\alpha$-internexin staining relative to that in the control mice in most brain regions of the null mice. At higher magnification, strong $\alpha$-internexin immunolabeling of cortical neurons was evident in both cell bodies (arrowheads) and neurites (arrows) in wild-type mice (Fig. 7M) but was limited to the cell bodies in hm-dko animals (Fig. 7N). These results indicate that the two larger neurofilament subunits are required for the efficient transport and assembly of $\alpha$-internexin in the axons. Western blot studies of different brain regions, including frontal cortex, hippocampus, cerebellum, and corpus callosum, confirmed the marked decrease in steady-state levels of $\alpha$-internexin in the absence of both NF-H and NF-M (Fig. 7O). The perikaryal accumulation of NF-L in the brains of hm-dko mice was also observed (data not shown), indicating its inefficient axonal transport in the absence of hetero-oligomer formation with NF-M and NF-H subunits in hm-dko mice (Yuan et al., 2003; Yuan, 2006).

Cerebellar granule cells, which were previously believed to contain only $\alpha$-internexin (Chien et al., 1996), also exhibited decreased levels of $\alpha$-internexin staining in the absence of both NF-M and NF-H (Fig. $7 K, L$ ). Parallel fibers, the axons of cerebellar granule cells, in hm-dko mice exhibited dramatically reduced staining of $\alpha$-internexin (Fig. 7L) compared with those from wild-type controls (Fig. $7 \mathrm{~K}$ ), suggesting that, despite their low abundance, neurofilament proteins may, in fact, be present in the parallel fibers of cerebellar granule cells. Using the monoclonal antibodies SMI31 and SMI33, which detect, respectively, a phosphorylated epitope on extensively phosphorylated isoforms of NF-H and NF-M, and a nonphosphorylated epitope accessible 


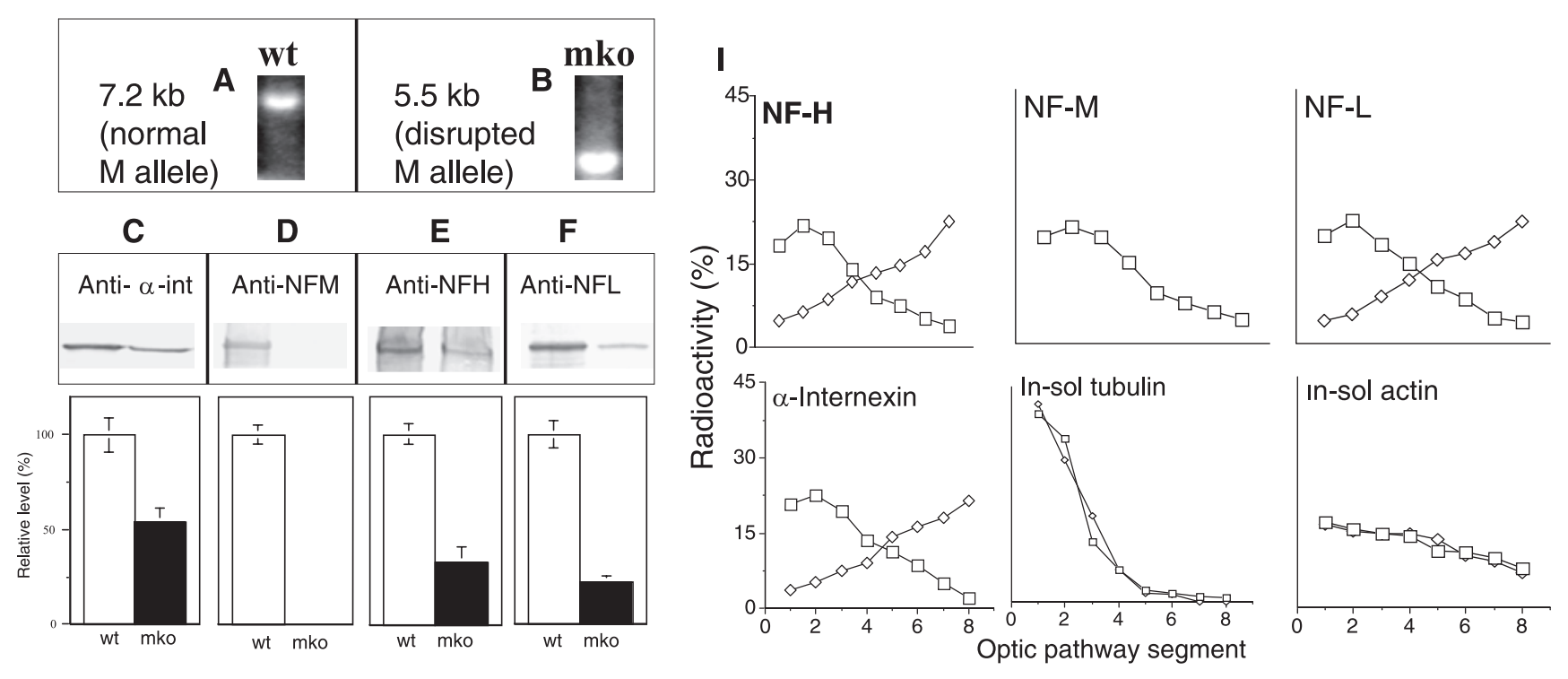

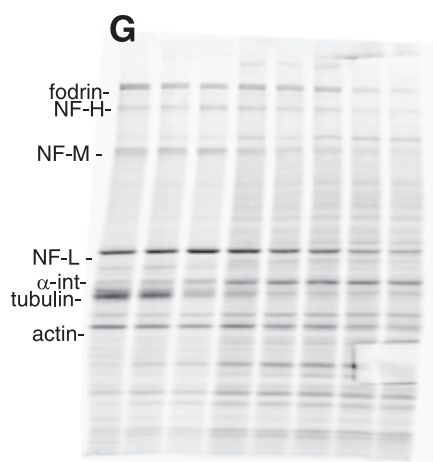

$\begin{array}{llllllll}1 & 2 & 3 & 4 & 5 & 6 & 7 & 8\end{array}$

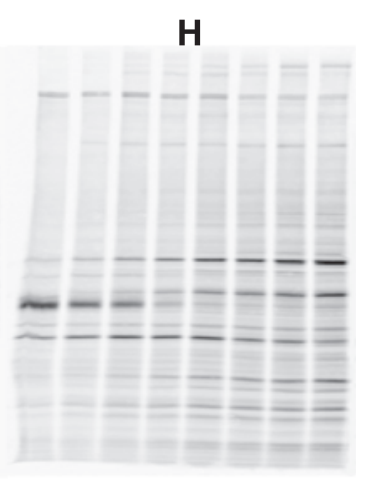

$\begin{array}{lllllllll}1 & 2 & 3 & 4 & 5 & 6 & 7 & 8\end{array}$

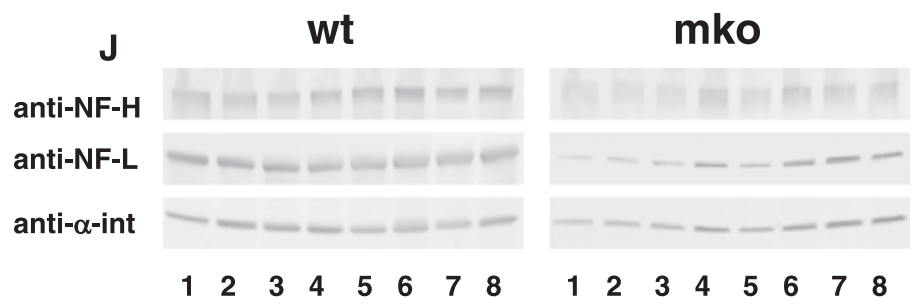

Figure 5. Effects of NF-M deletion on transport rates and levels of $\alpha$-internexin, NF-L, and NF-H in optic axons. $A, B$, Mouse genomic DNA was screened for targeted disruption of NF-M homozygous mice through genotyping the NF-M loci by hybridizing with a sequence from NF-M. C-F, On immunoblots of $10-20 \mu \mathrm{g}$ of total optic nerve protein extract from 3-to 4-month-old mice, $\alpha$-internexin and neurofilament triplet subunits were identified with mAbs to $\alpha$-internexin, NF-M, NF-H, and NF-L (C, $\mathbf{D}, \boldsymbol{E}$, and $\boldsymbol{F}$, respectively), relative levels of each protein were determined by $\mathrm{NIH}$ imaging. Measurements are mean \pm SD from four animals for each group. In the absence of NF-M protein (D), the levels of $\alpha$-internexin, NF-H, and NF-L proteins were $54 \pm 8 \%(\boldsymbol{C}), 33 \pm 8 \%$ $(\boldsymbol{E})$, and $22 \pm 3 \%(\boldsymbol{F})$ of the wild-type level, respectively. $\mathbf{G}-\mathbf{I}$, Slow axonal transport analyses, after intravitreal injection of ${ }^{35} S$-methionine in control $(\boldsymbol{G})$ and $\mathrm{mko}$ mice $(\boldsymbol{H})$, demonstrate increased velocities of $\alpha$-internexin, NF-H, and NF-L and unchanged rates of Triton-insoluble tubulin and actin in mko mice $(I)$. J, Distribution of $\alpha$-internexin, NF- $H$, and NF-L in mko along optic pathway compared with that in wild-type mice. The squares represent wild-type control, and diamonds represent knock-out mice.

on both phosphorylated and nonphosphorylated isoforms of NF-H and NF-M, we confirmed in wild-type mice that the parallel fibers or axons (both thick and thin) of cerebellar granule cells contain low levels of these two neurofilament subunits (Fig. $8 A, C$ ), but those of hm-dko animals do not (Fig. $8 B, D$ ). The presence of neurofilament proteins in granule cell parallel fibers was also confirmed by immunolabeling with the monoclonal anti-NF-H antibody N52 (Fig. 8E) or with a monoclonal antibody to NF-M (NN18) and NF-L (NR4) at high concentrations (data not shown). Doublelabeling studies showed that parallel fiber immunolabeling by anti-NF-H antibody (Fig. $8 F$ ) and anti- $\alpha$-internexin antibody (Fig. $8 G$ ) overlapped (Fig. $8 H$ ). Our data are consistent with previous findings showing that limited amounts of neurofilament mRNA or protein may be present in cerebellar granule cells (Liesi et al., 1986; Gilad et al., 1989; Vitadello and DenisDonini, 1990; Dahlstrand et al., 1995; Riederer et al., 1996). The data demonstrate that the presence of even low levels of NF-M and NF-H in cerebellar granule cells are critical for the efficient axonal transport and function of $\alpha$-internexin.

\section{Deletion of $\alpha$-internexin modifies transport and levels of neurofilament subunits}

We generated mice with $\alpha$-internexin and NF-M double knockout by cross breeding $\alpha$-iko with mko. Mouse genomic DNA screening confirmed targeted disruption of $\alpha$-internexin (Fig. $9 A, B)$ and NF-M (Fig. 9C,D) in homozygous mice, and Western blot analysis confirmed the absence of $\alpha$-internexin and NF-M protein in $\alpha$-im-dko mice (Fig. 9E,F). The levels of NF-H and NF-L proteins were decreased by $73 \%$ (Fig. $9 G$ ) and $83 \%$ (Fig. $9 \mathrm{H}$ ) of the corresponding levels in control mice, respectively. Slow axonal transport was determined by intravitreal injection of ${ }^{35} \mathrm{~S}$-methionine at $14 \mathrm{~d}$ after injection. As shown in Figure 9, transport of radiolabeled NF-H and NF-L in wild-type mice was readily seen (Figs. 9I) but was undetectable in $\alpha$-im-dko (Fig. 9J) even after film exposure of over 3 months. Therefore, deletion of $\alpha$-internexin potentiated the effects of NF-M deletion on NF-L and NF-H seen in Figure 5. Deletion of $\alpha$-internexin alone, like NF-H deletion alone (Rao et al., 2002a), has no apparent effect on transport of the other subunits (Yuan et al., 2003). Because of the potential redundancy of subunit functions, we investigated ef- 

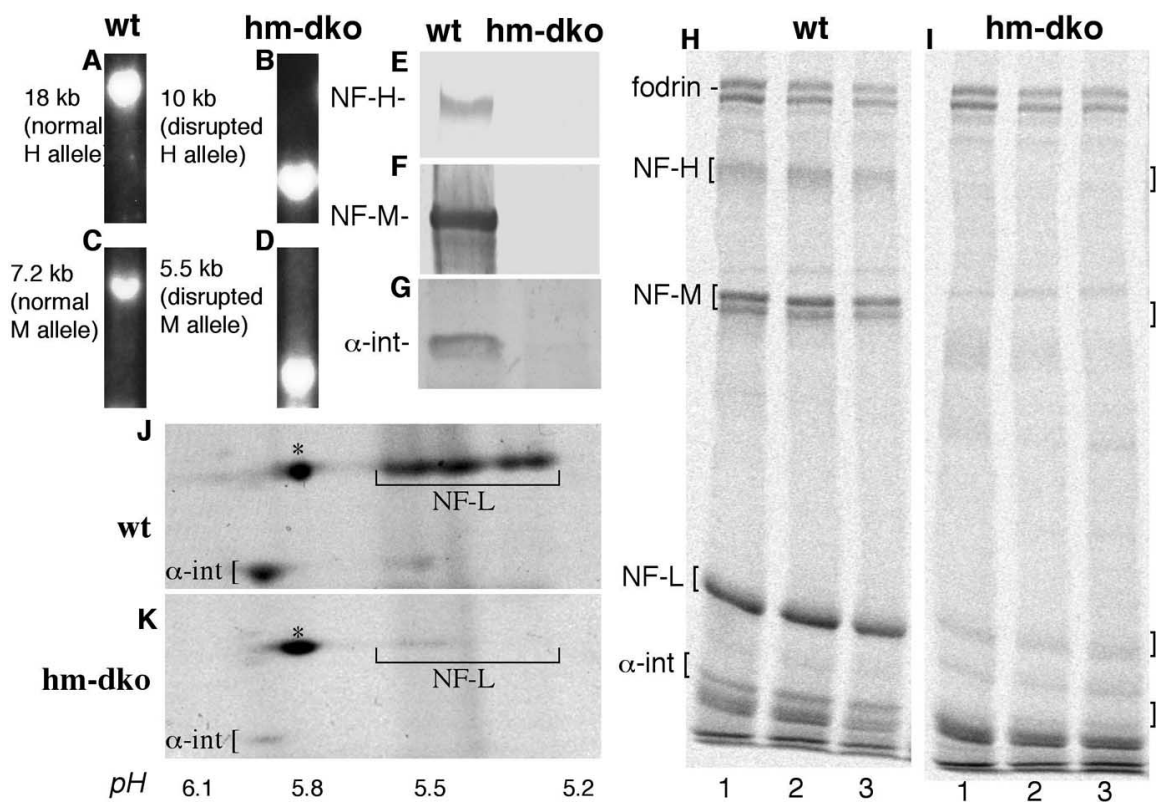

Figure 6. Effects of combined deletion of NF-H and NF-M on $\alpha$-internexin and NF-L transport and levels in optic axons. hm-dko mice were generated by crossbreeding and screening. $A-D$, Mouse genomic DNA was screened for targeted disruption of both $\mathrm{NF}-\mathrm{H}(\boldsymbol{A}, \boldsymbol{B})$ and NF-M $(\boldsymbol{C}, \boldsymbol{D})$ homozygous mice through genotyping the NF-H and NF-M loci by hybridizing with a sequence from NF-H or NF-M. NF-H, NF-M, and $\alpha$-internexin ( $\alpha$-int) were identified by immunoblots of total optic nerve protein $(10-20 \mu \mathrm{g})$ from 3- to 4-month-old mice using mAbs to NF-H (N52), NF-M (NN18), and $\alpha$-internexin (MAB5224), respectively. E-G, In mice lacking NF-H and NF-M $(\boldsymbol{E}, \boldsymbol{F}), \alpha$-internexin levels are $<10 \%$ of wild-type (wt) levels detected by immunoblotting (G), and NF-L proteins are barely detectable as shown previously (Yuan et al., 2003). $\boldsymbol{H}, \mathbf{I}$, Slow axonal transport analyses (7 d after injection) in wild-type control $(\boldsymbol{H})$ and hm-dko mice $(\boldsymbol{I})$, as in Figure 5, reveal barely detectable transport of $\alpha$-internexin in hm-dko axons compared with wild-type mice. The positions of cytoskeletal proteins are indicated, and the nerve segments are numbered below the gels consecutively from the level of the eye. $\boldsymbol{J}, \boldsymbol{K}, 2 \mathrm{D}$ transport analyses ( $7 \mathrm{~d}$ after injection) confirm dramatically reduced transport of $\alpha$-internexin into hm-dko axons. The asterisks in $\boldsymbol{J}$ and $\boldsymbol{K}$ indicate $\mathrm{Hsc70.}$

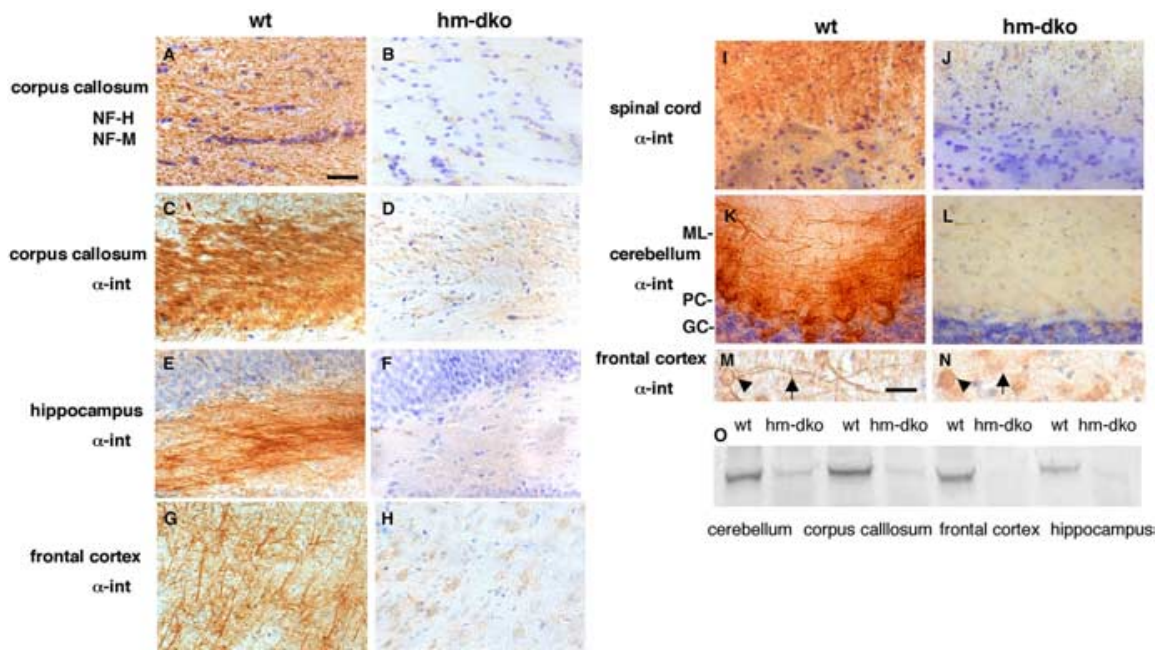

Figure 7. $\quad \alpha$-Internexin depletion from CNS axons in NF-H and NF-M double-deleted mice. Immunoactivity of $\alpha$-internexin was detected with MAB5224 $(\boldsymbol{C}-\boldsymbol{N})$ and of NF-H and NF-M $(\boldsymbol{A}, \boldsymbol{B})$ detected with SMI33. $\boldsymbol{A}, \boldsymbol{B}, \mathrm{NF}-\mathrm{H}$ and NF-M were absent in $\mathrm{hm}$-dko mice as shown in corpus callosum. $\boldsymbol{C}-\boldsymbol{L}, \alpha$-Internexin was markedly depleted from axons in all CNS regions, including corpus callosum $(\boldsymbol{C}, \boldsymbol{D})$, the polymorph layer of hippocampus $(\boldsymbol{E}, \boldsymbol{F})$, frontal cortex $(\boldsymbol{G}, \boldsymbol{H})$, spinal cord $(\boldsymbol{I}, \boldsymbol{J})$, and cerebellum $(\boldsymbol{K}, \boldsymbol{L})$. $\boldsymbol{M}, \boldsymbol{N}$, At higher magnification, $\alpha$-internexin immunolabeling of cortical neurons includes cell bodies (arrowheads) and neurites (arrows) in wild-type mice $(\boldsymbol{M})$; but in hm-dko $\alpha$-internexin, immunolabeling was limited to the cell bodies $(\boldsymbol{N})$. $\boldsymbol{0}$, Western blot analysis confirms the marked $\alpha$-internexin reductions. Scale bars: $\boldsymbol{A}-\mathbf{L}, 30 \mu \mathrm{m} ; \boldsymbol{M}, \boldsymbol{N}, 15 \mu \mathrm{m}$. ML, Molecular layer; PC, Purkinje cells; GC, granule cells.

fects of $\alpha$-internexin deletion further in NF-H-deleted mice by cross breeding $\alpha$-iko with hko. Mouse genomic DNA screening confirmed targeted disruption of both $\alpha$-internexin (Fig. 10A, B) and NF-H (Fig. 10C,D) in homozygous mice, and Western blot analysis confirmed the absence of $\alpha$-internexin and NF-H protein in $\alpha$-ihdko mice (Fig. 10E,F). Levels of NF-M and NF-L proteins did not significantly change (Fig. 10G,H) (mean $\pm \mathrm{SD} ; n=4)$; however, their axonal transport was selectively accelerated, because actin and cytoskeletal and soluble forms of tubulin translocated normally at $14 \mathrm{~d}$ (Fig. 10) and $21 \mathrm{~d}$ (data not shown) after injection.

\section{$\alpha$-Internexin and NF-L exhibit identical} axonal transport defects and mislocation in NF-H-LacZ transgenic mice

NF-H-LacZ transgenic mice express a fusion protein in which the $\mathrm{C}$ terminus of $\mathrm{NF}-\mathrm{H}$ is replaced by $\beta$-galactosidase and develop marked perikaryal accumulations of neurofilaments and reduced neurofilament transport, mimicking patterns seen in several human neurodegenerative diseases (Eyer and Peterson, 1994; Al-Chalabi and Miller, 2003). In 2D gel analyses of these mice, we observed that $\alpha$-internexin, behaving like NF-L, was proportionally reduced to $<25 \%$ of wild-type levels, whereas insoluble tubulin, actin, and spectrin did not change significantly (Fig. $11 A-D)$. Like NF-L, $\alpha$-internexin also accumulated in the retina containing the cell bodies of retinal ganglion cells in the NFH-LacZ mutant mice (Fig. 11E,F).

\section{Discussion}

Neurofilaments have universally been considered to be composed of three subunits. Another neuronal intermediate filament protein, $\alpha$-internexin, which has been implicated along with neurofilaments in neurological disease, has been regarded as a component of an independent filament system with unknown function. In this study, we demonstrate, by all criteria previously used to establish the neurofilament "triplet proteins" as subunits of the neurofilaments, that $\alpha$-internexin functions in the adult CNS principally as a fourth subunit of neurofilaments. Although $\alpha$-internexin has been known to be a neuronal IF protein based on its coassembly in vitro with triplet proteins (Ching and Liem, 1993), this property does not establish it as a neurofilament subunit. Nestin and vimentin are also IF proteins in neurons but are not part of the neurofilament, and in vitro coassembly into heteropolymers occurs between $\alpha$-internexin and other IF proteins, such as vimentin and keratin, which are clearly not neurofilament subunits (Monteiro and Cleveland, 1989; Carter et al., 1997; Beaulieu et al., 1999). $\alpha$-Internexin copurified with the neurofilament triplet proteins from Triton-insoluble fractions in amounts comparable with 

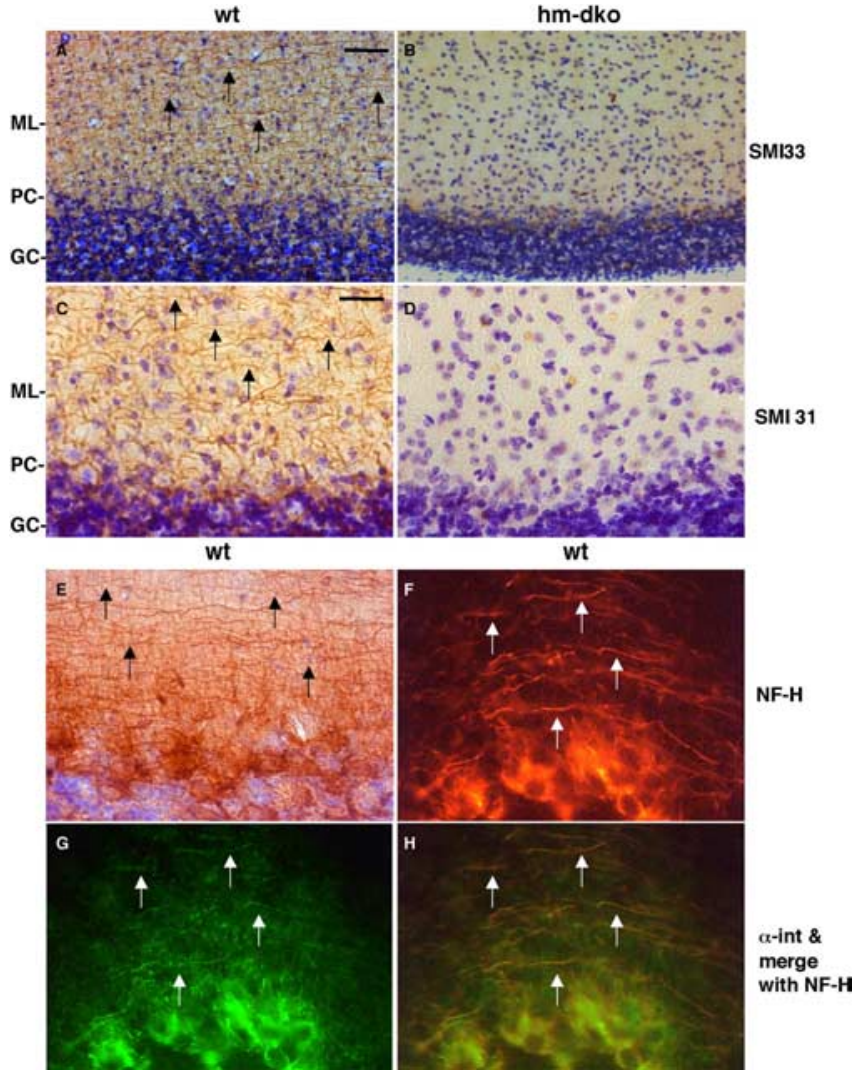

Figure 8. Presence of low-level NF-H and NF-M in the parallel fibers of cerebellar granule cells in wild-type (wt) mice. $\boldsymbol{A}-\boldsymbol{D}$, Immunocytochemistry with SMI 33 and SMI 31 antibodies confirms the presence of low-level NF-H and NF-M in the parallel fibers of cerebellar granule cells in wild-type mice $(\boldsymbol{A}, \boldsymbol{C})$ and their absence in $\mathrm{hm}$-dko mice $(\boldsymbol{B}, \boldsymbol{D})$. $\boldsymbol{E}-\boldsymbol{H}$, Anti-NF-H antibody N52 detects NF-H in the parallel fiber $(\boldsymbol{E})$ and demonstrates its colocalization with $\alpha$-internexin $(\boldsymbol{F}-\boldsymbol{H})$. $\boldsymbol{A}$ and $\boldsymbol{B}$ were stained with SMI33, and $\boldsymbol{C}$ and $\boldsymbol{D}$ were stained with SMI31. $\boldsymbol{E}$ and $\boldsymbol{F}$ were stained with N52, and $\boldsymbol{G}$ was stained with $\alpha$-internexin antibody. $\boldsymbol{H}$ is the merge of $\boldsymbol{F}$ and $\boldsymbol{G}$. ML, Molecular layer; PC, Purkinje cells; GC, granule cells. The arrows point to parallel fibers. Scale bars: $\boldsymbol{A}, \boldsymbol{B}, 160 \mu \mathrm{m} ; \boldsymbol{C}-\boldsymbol{H}, 40 \mu \mathrm{m}$.

those of the other subunits and exhibited a stable stoichiometry with NF-L in different CNS regions and under normal and abnormal conditions in which neurofilament levels vary. We also demonstrated, for the first time, that $\alpha$-internexin coassembles with all three neurofilament proteins into single filamentous network in quadruple-transfected SW13vim(-) cells and colocalizes with NF-M on the same neurofilament in optic axon from normal mice. Based on observations that the molar ratio of the neurofilament triplet isolated from bovine spinal cord myelinated axons is 4:2:1 (NF-L:NF-M:NF-H) (Scott et al., 1985) and the molar ratio of NF-L to $\alpha$-internexin is $\sim 2: 1$, we calculate that the molar ratio of the quadruplets in isolated axonal neurofilaments from optic nerve and spinal cord is 4:2:2:1 (NF-L: $\alpha$-internexin:NF-M:NF-H). The stoichiometry of radiolabeled $\alpha$-internexin and NF-L was maintained during axonal transport even after substantial times, indicating that NF-L and $\alpha$-internexin in axons have the same turnover rate. Highresolution, two-dimensional, gel electrophoresis showed unequivocally that $\alpha$-internexin is transported at the same rate as the triplets, consistent with previous one-dimensional gel analyses indicating transport of $\alpha$-internexin and NF-L at similar rates in rat optic nerve (Kaplan et al., 1990).

A functionally meaningful association of $\alpha$-internexin with the neurofilament triplet in vivo was strongly supported by addi- wt

$\alpha$-im-dko

\begin{tabular}{|l|l|}
\hline $\begin{array}{l}11.5 \mathrm{~kb} \quad \mathrm{~A} \\
\text { (normal } \\
\alpha \text {-int allele) }\end{array}$ & $\begin{array}{l}8.5 \mathrm{~kb} \quad \text { B } \\
\text { (disrupted } \\
\alpha \text {-int allele) }\end{array}$ \\
\hline $\begin{array}{l}7.2 \mathrm{~kb} \text { C } \\
\text { (normal } \\
\text { M allele) }\end{array}$ & $\begin{array}{l}5.5 \mathrm{~kb} \text { D } \\
\text { (disrupted } \\
\text { M allele) }\end{array}$ \\
\hline
\end{tabular}

E $\quad F$

G

H

Antiø-int Anti-NF-M Anti-NF-H Anti-NF-L
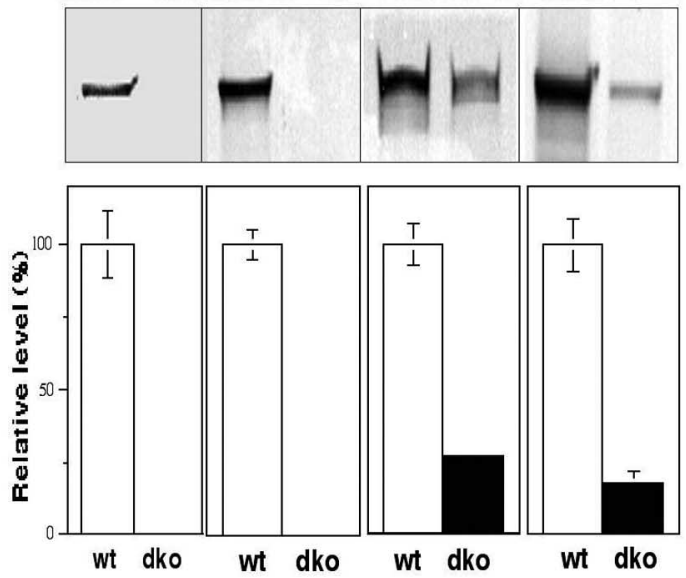

I

$\mathbf{J}$

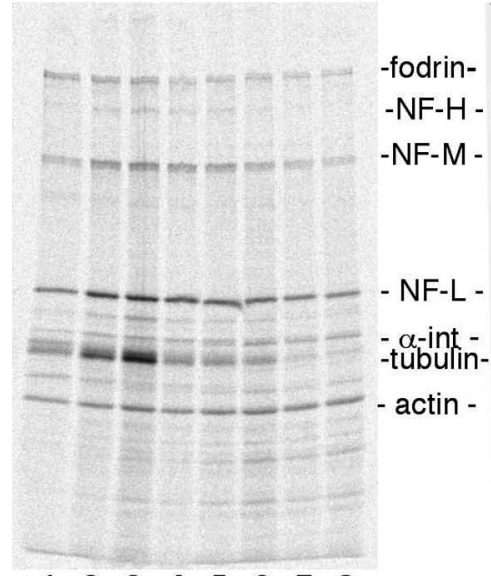

$\begin{array}{llllllll}1 & 2 & 3 & 4 & 5 & 6 & 7 & 8\end{array}$ wt

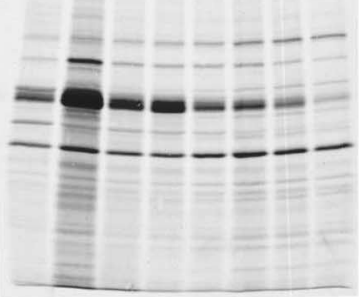

$\begin{array}{llllllll}1 & 2 & 3 & 4 & 5 & 6 & 7 & 8\end{array}$

$\alpha$-im-dko

Figure 9. Effects of combined deletion of $\alpha$-internexin and NF-M on levels and transport of NF-H and NF-L in optic axons. $\alpha$-Im-dko mice were generated by crossbreeding and screening. $A-D$, Mouse genomic DNA was screened for targeted disruption of both $\alpha$-internexin $(A, B)$ and NF-M $(\boldsymbol{C}, \boldsymbol{D})$ homozygous mice through genotyping the $\alpha$-internexin and NF-M loci by hybridizing with a sequence from $\alpha$-internexin or NF-M. $\mathbf{E}-\boldsymbol{H}$, Immunoblot analyses of total optic nerve proteins (10-20 $\mu \mathrm{g})$ from 3- to 4-month-old mice using mAbs to $\alpha$-internexin, NF-M, $\mathrm{NF}-\mathrm{H}$, and NF-L ( $\boldsymbol{E}, \boldsymbol{F}, \boldsymbol{G}$, and $\boldsymbol{H}$, respectively) demonstrated the absence of $\alpha$-internexin and NF-M protein in $\alpha$-im-dko mice $(\boldsymbol{E}, \boldsymbol{F})$ and decreased levels of NF-H (27 $\pm 2 \%)(\boldsymbol{G})$ and NF-L $17 \pm 5 \%(\boldsymbol{H})$, respectively, compared with wild-type mice. Measurements are mean \pm SD from four animals for each group. Slow axonal transport analyses $14 \mathrm{~d}$ after injection indicates undetectable radiolabeled NF-H and NF-L transport even after exposing films for 3 months in $\alpha$-im-dko mice (J). The appearance of the dark band in $J$, lane 2, is labeled insoluble tubulin because of long-time $(90 \mathrm{~d})$ exposure in the mutant $(\boldsymbol{H})$ versus short-time $(10 \mathrm{~d})$ exposure in the wild-type control (I). 


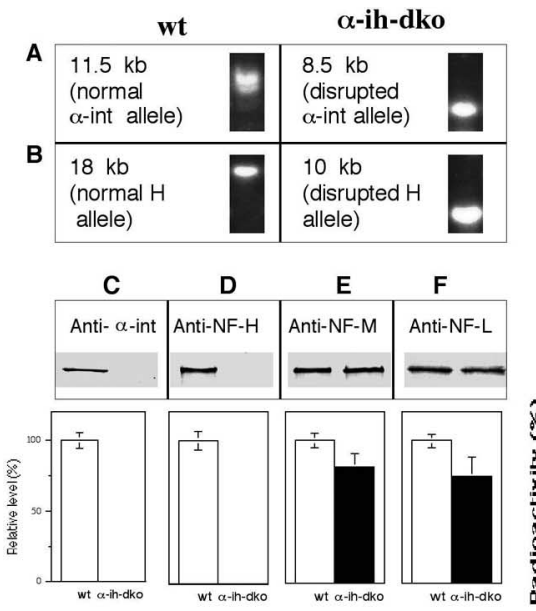

G

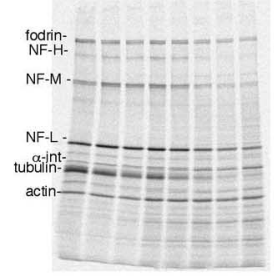

$\begin{array}{llllllll}1 & 2 & 3 & 4 & 5 & 6 & 7 & 8\end{array}$
H

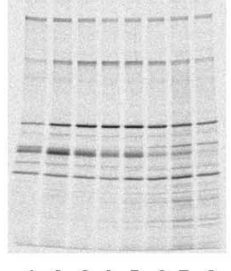

$\begin{array}{llllllll}1 & 2 & 3 & 4 & 5 & 6 & 7 & 8\end{array}$
I

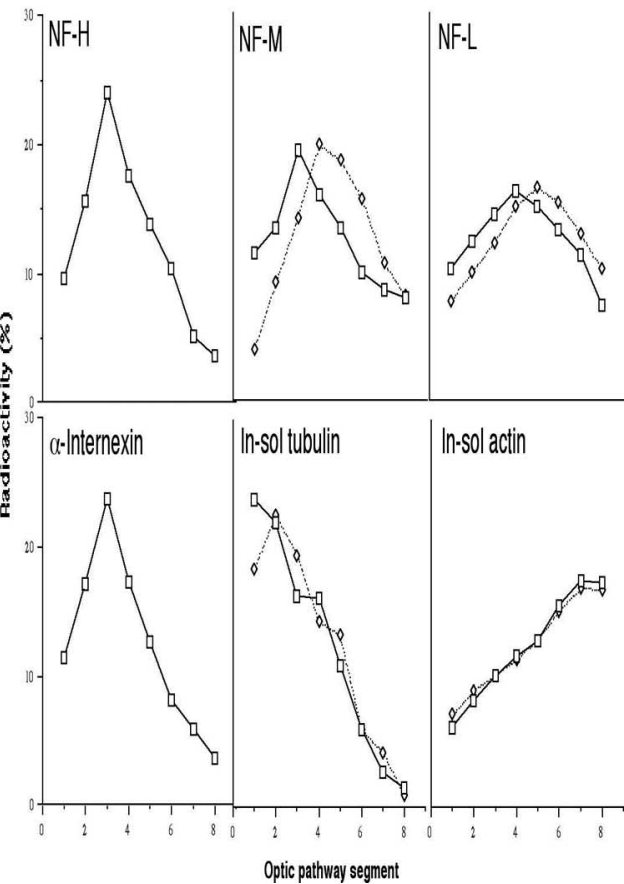

Figure 10. Effects of combined $\alpha$-internexin and NF-H deletion on the transport of NF-L and NF-M in optic axons. $\alpha$-Ih-dko mice were generated by crossbreeding and screening. $\boldsymbol{A}, \boldsymbol{B}$, Mouse genomic DNA was screened for targeted disruption of both $\alpha$-internexin $(\boldsymbol{A})$ and NF-H $(\boldsymbol{B})$ homozygous mice through genotyping the $\alpha$-internexin and NF-H loci by hybridizing with a sequence from $\alpha$-internexin or NF-H. C-F, Immunoblot analyses of optic nerve proteins $(10-20 \mu \mathrm{g})$ from 3-to 4-month-old mice with mAbs to $\alpha$-internexin, NF-H, NF-M, and NF-L ( $\boldsymbol{C}, \boldsymbol{D}, \boldsymbol{E}$, and $\boldsymbol{F}$, respectively) demonstrates the absence of $\alpha$-internexin $(\boldsymbol{C})$ and $\mathrm{NF}$-H protein in $\alpha$-ih-dko mice $(\boldsymbol{D})$ but unchanged levels of NF-M $(\boldsymbol{E})$ and NF-L $(\boldsymbol{F})$. Measurements are mean \pm SD from four animals for each group. $\mathbf{G}-\mathbf{I}$, Slow axonal transport analyses (14 d after injection) revealed increased velocity (I) of NF-L and NF-M transport in $\alpha$-ih-dko mice $(\boldsymbol{H})$ compared with control mice $(\boldsymbol{G})$. Note the increased velocity of NF-L and NF-M transport mainly at the location of neurofilament bulk but not the leading edge in $\alpha$-ih-dko mice. The squares represent wild-type control, and diamonds are knock-out mice.

tional studies of axonal transport in a series of neurofilament subunit knock-out mice. Indeed, $\alpha$-internexin appears to be more integral to neurofilament transport than NF-H, because deleting $\alpha$-internexin in the absence of NF-L reduces NF-M transport to undetectable levels, whereas deleting NF-H in the absence of NF-L has no apparent effect on NF-M transport (Yuan et al., 2003). Loss of NF-M greatly reduced levels and accelerated transport of not only NF-L and NF-H, as shown previously in peripheral nerve (Jacomy et al., 1999), but also $\alpha$-internexin, indicating a close association among these proteins. The effect on $\alpha$-internexin transport and levels in axons was even more dramatic when both NF-H and NF-M were deleted. Conversely, $\alpha$-internexin deletion influenced the behaviors of the triplet proteins. Deletion of $\alpha$-internexin in the absence of NF-H accelerated the transport of NF-M and NF-L, indicating that $\alpha$-internexin interacts with NF-M or NF-L or both during transport under these conditions. The fact that neurofilament transport is affected only after deletion of both $\alpha$-internexin and NF-H, but not either NF-H alone (Rao et al., 2002a) or $\alpha$-internexin alone (Yuan et al., 2003), implies redundancy of function or cooperation between $\alpha$-internexin and NF-H.

Our results coupled with previous findings on the importance of an $\alpha$-internexin-NF-M partnership for neurofilament transport (Yuan et al., 2003) strongly suggest that one function of $\alpha$-internexin in neurofilaments is to facilitate transport of these assemblies. The fact that deletion of $\alpha$-internexin in the absence of NF-M lowered transport and levels of labeled NF-H and NF-L in axons to barely detectable levels supports the idea that, in addition to partnering with the NF-M subunit, some $\alpha$-internexin also partners with NF-H and NF-L subunits.

The functional contribution of $\alpha$-internexin as a fourth subunit of the neurofilament likely extends beyond its facilitatory role in filament transport. Each subunit of the neurofilament is known to interact with different subsets of proteins and organelles. For example, NF-L interacts specifically with myosin $\mathrm{Va}$ (Rao et al., 2002b), microtubule-associated proteins (Heimann et al., 1985), and the NR1 subunit of the NMDA receptor (Ehlers et al., 1998; Ratnam and Teichberg, 2005), whereas the dopamine $\mathrm{D}_{1}$ receptor (Kim et al., 2002) and mitochondria (Wagner et al., 2003) bind separately to the NF-M and NF-H subunits, respectively. Therefore, the heteropolymeric neurofilaments may provide a platform for integrating diverse macromolecules into functional units. Variations in subunit stoichiometry in different neuronal populations and different domains of neurons (Hirokawa et al., 1984) may allow this platform to be tailored to coordinate specialized functions in a particular neuron type or location within a neuron. Neurofilaments differ in length in axons and dendrites (Burton and Wentz, 1992; Brown, 1997; Kong et al., 1998), and the proportions and phosphorylation states of NF-H, in particular, are highly variable (Hirokawaet al., 1984; Pachter and Liem, 1984; Archer et al., 1994). Like NF-H, $\alpha$-internexin present in varying proportions in neurofilaments extends the functional capacities of neurofilaments. $\alpha$-Internexin, for example, binds selectively to the membrane cytoskeletal protein 4.1R and to other scaffold proteins of the postsynaptic density (Jing-Ping et al., 2005; Suzuki et al., 2005), suggesting that $\alpha$-internexin may facilitate the integration of neurofilaments with membrane-associated cytoskeletal and receptor components. The higher proportions of $\alpha$-internexin in dendritic spines (Benson et al., 1996) and at postsynaptic densities (Suzuki et al., 1997) are consistent with this role.

Greater proportions of $\alpha$-internexin in a neurofilament have also been proposed previously to confer greater plasticity to the neurofilament network (Nixon and Shea, 1992; Giasson and Mushynski, 1997), perhaps by modifying the cross-linking capabilities of neurofilament populations (Vickers et al., 1992; Giasson and Mushynski, 1997). It has been shown recently that, even in the adult brain, small axons may be highly dynamic (Stettler et al., 2006). The relatively high proportions of $\alpha$-internexin in the neurofilaments of small-caliber axons seen in this study and in others (Kaplan et al., 1990; Fliegner et al., 1994) may facilitate this greater degree of plasticity in adult and developing brain, as also suggested by the facilitatory effect of $\alpha$-internexin on axonal neurite elongation (Shea and Beermann, 1999). Our findings imply that $\alpha$-internexin in mature neurons likely performs the forego- 


\section{WT NF-H-LacZ}
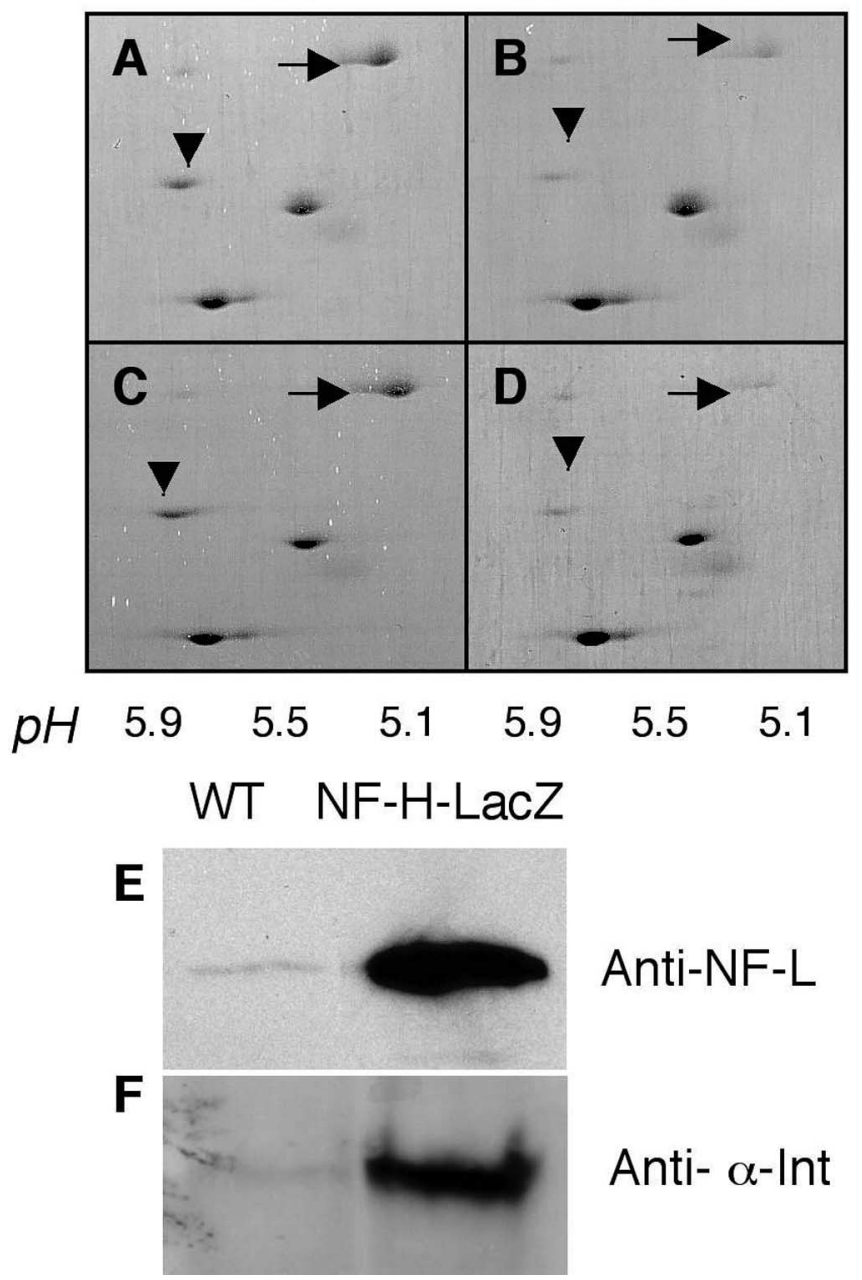

Figure 11. $\quad \alpha$-Internexin and NF- $L$ transport and levels in optic axons and in retinas containing retinal ganglion cell bodies in NF-H-LacZ transgenic mice. $A-D$, Quantification image analysis of Coomassie blue-stained 2D gels indicates that $\alpha$-internexin (arrowheads) and NF-L (arrows) in NF-H-LacZ transgenic mice were $<25 \%$ of wild-type levels, whereas insoluble tubulin, actin, and spectrin were not changed. $\boldsymbol{E}, \boldsymbol{F}$, Levels of $\alpha$-internexin and NF-L in the retina containing retinal ganglion cell bodies are increased in NF-H-LacZ transgenic mice compared with control mice.

ing possible functions as a component of neurofilaments, rather than as an independent filament system.

$\alpha$-Internexin pathology has been increasingly reported in neurodegenerative diseases associated with neurofilament accumulation or mislocation. Our evidence that $\alpha$-internexin is a neurofilament subunit in adult CNS provides a basis for this close association. $\alpha$-Internexin is prominent in the neurofilament inclusions that are hallmark of neuronal intermediate filament inclusion body disease, a form of frontal temporal dementia (Cairns et al., 2004a). In tropical spastic paraparesis, a degenerative neurological disorder, $\alpha$-internexin interacts selectively with the human T-cell leukemia virus transcriptional transactivator Tax leading to cytoskeletal disorganization and marked neurofilament accumulation (Wu et al., 1993; Liberski et al., 1994, 1999; Reddy et al., 1998). Notably, NF-L mutations cause type $2 \mathrm{E}$ and $1 \mathrm{~F}$ forms of Charcot-Marie-Tooth disease, the most common inherited peripheral nerve disorder (Mersiyanova et al., 2000; De Jonghe et al., 2001; Georgiou et al., 2002; Yoshihara et al., 2002; Jordanova et al., 2003; Zuchner et al., 2004). It is inter- esting to speculate that the presence of $\alpha$-internexin could make the CNS neurofilament network more resistant than that of the PNS to the loss of NF-L function in the disease by facilitating NF-M and NF-H assembly and transport. Consistent with this possibility is the finding that NF-M is still transported and assembled with $\alpha$-internexin in optic axons without NF-L, although the mutant axons are smaller and have fewer neurofilaments than wild-type controls (Zhu et al., 1997; Yuan et al., 2003).

In supporting the role of $\alpha$-internexin as a fourth subunit of neurofilament, our data do not conflict with previous data, nor do they exclude the possibility that, in addition to assembling into neurofilaments in the mature CNS, $\alpha$-internexin may form homopolymeric filaments at some earlier stage in development. It should also be noted that even during the peak of late embryonic expression of $\alpha$-internexin, NF-M, the critical partner for subunit transport, is also expressed, albeit at low levels (FaussonePellegrini et al., 1999; Undamatla and Szaro, 2001). Levels of $\alpha$-internexin expression are believed to be higher during late embryonic development and to be reduced to some extent postnatally (Kaplan et al., 1990; Usui et al., 1996). Our data emphasize, however, that despite somewhat lowered expression of mRNA, protein levels of $\alpha$-internexin are in the same range as the "triplet proteins," which are among the most abundant proteins in the brain. Although the reported undetectable level of neurofilament proteins in cerebellar granule cells has been viewed as support for an independent $\alpha$-internexin filament system, we found that granule cell neurons do, in fact, contain low levels of triplet proteins, and deletion of these subunits depletes $\alpha$-internexin from the axons of these cells.

Although $\alpha$-internexin is initially expressed in peripheral axons, its expression is markedly downregulated during embryonic development and is not easily detectable in most adult peripheral tissues. The developmental disappearance of $\alpha$-internexin in the PNS coincides with the appearance of another intermediate filament protein, peripherin. Peripherin, a type III intermediate filament protein, assembles with NF-L in SW13 cells devoid of endogenous intermediate filaments (Beaulieu et al., 1999) and is found with the neurofilament triplet proteins in the same filament in PC12 cells and in some neurofilaments from sciatic nerve (Parysek et al., 1991). A frameshift deletion in the peripherin gene has been shown recently to disrupt neurofilament assembly in a subgroup of cases of amyotrophic lateral sclerosis (ALS) (GrosLouis et al., 2004). In one ALS case, a pathogenic peripherin gene mutation was associated with distinctive large perikaryal aggregates containing peripherin and neurofilament triplet (Leung et al., 2004). These observations strongly suggest that peripherin interacts with neurofilaments in vivo and possibly serves a role in the PNS analogous to $\alpha$-internexin. To establish this possibility will require systematic molecular genetic studies of peripherin and neurofilament subunits together with investigations of these proteins with respect to stoichiometry, axonal transport and turnover, coassembly, and ultrastructural colocalization. Our results would suggest that differences in neurofilament composition between the CNS and PNS should now be considered as a possible contributing factor to the differential vulnerability of these neural systems to pathological states.

\section{References}

Al-Chalabi A, Miller CC (2003) Neurofilaments and neurological disease. BioEssays 25:346-355.

Archer DR, Watson DF, Griffin JW (1994) Phosphorylation-dependent immunoreactivity of neurofilaments and the rate of slow axonal transport in the central and peripheral axons of the rat dorsal root ganglion. J Neurochem 62:1119-1125. 
Beaulieu JM, Robertson J, Julien JP (1999) Interactions between peripherin and neurofilaments in cultured cells: disruption of peripherin assembly by the NF-M and NF-H subunits. Biochem Cell Biol 77:41-45.

Benson DL, Mandell JW, Shaw G, Banker G (1996) Compartmentation of alpha-internexin and neurofilament triplet proteins in cultured hippocampal neurons. J Neurocytol 25:181-196.

Brown A (1997) Visualization of single neurofilaments by immunofluorescence microscopy of splayed axonal cytoskeletons. Cell Motil Cytoskeleton 38:133-145.

Burton PR, Wentz MA (1992) Neurofilaments are prominent in bullfrog olfactory axons but are rarely seen in those of the tiger salamander, Ambystoma tigrinum. J Comp Neurol 317:396-406.

Cairns NJ, Perry RH, Jaros E, Burn D, McKeith IG, Lowe JS, Holton J, Rossor MN, Skullerud K, Duyckaerts C, Cruz-Sanchez FF, Lantos PL (2003) Patients with a novel neurofilamentopathy: dementia with neurofilament inclusions. Neurosci Lett 341:177-180.

Cairns NJ, Zhukareva V, Uryu K, Zhang B, Bigio E, Mackenzie IR, Gearing M, Duyckaerts C, Yokoo H, Nakazato Y, Jaros E, Perry RH, Lee VM, Trojanowski JQ (2004a) alpha-Internexin is present in the pathological inclusions of neuronal intermediate filament inclusion disease. Am J Pathol 164:2153-2161.

Cairns NJ, Uryu K, Bigio EH, Mackenzie IR, Gearing M, Duyckaerts C, Yokoo H, Nakazato Y, Jaros E, Perry RH, Arnold SE, Lee VM, Trojanowski JQ (2004b) alpha-Internexin aggregates are abundant in neuronal intermediate filament inclusion disease (NIFID) but rare in other neurodegenerative diseases. Acta Neuropathol (Berl) 108:213-223.

Cairns NJ, Grossman M, Arnold SE, Burn DJ, Jaros E, Perry RH, Duyckaerts C, Stankoff B, Pillon B, Skullerud K, Cruz-Sanchez FF, Bigio EH, Mackenzie IR, Gearing M, Juncos JL, Glass JD, Yokoo H, Nakazato Y, Mosaheb S, Thorpe JR, Uryu K, Lee VM, Trojanowski JQ (2004c) Clinical and neuropathologic variation in neuronal intermediate filament inclusion disease. Neurology 63:1376-1384.

Carter JE, Robertson J, Anderton BH, Gallo JM (1997) Incorporation of NF-L into keratin filaments in transfected epithelial cells. NeuroReport 8:2225-2228.

Chien CL, Mason CA, Liem RK (1996) alpha-Internexin is the only neuronal intermediate filament expressed in developing cerebellar granule neurons. J Neurobiol 29:304-318.

Ching GY, Liem RK (1993) Assembly of type IV neuronal intermediate filaments in nonneuronal cells in the absence of preexisting cytoplasmic intermediate filaments. J Cell Biol 122:1323-1335.

Ching GY, Chien CL, Flores R, Liem RK (1999) Overexpression of $\alpha$-internexin causes abnormal neurofilamentous accumulations and motor coordination deficits in transgenic mice. J Neurosci 19:2974-2986.

Chiu FC, Barnes EA, Das K, Haley J, Socolow P, Macaluso FP, Fant J (1989) Characterization of a novel $66 \mathrm{kd}$ subunit of mammalian neurofilaments. Neuron 2:1435-1445.

Cooper GM, Hausman RE (2003) The cell: a molecular approach, Ed 3, p 713. Sunderland, MA: Sinauer.

Dahlstrand J, Lardelli M, Lendahl U (1995) Nestin mRNA expression correlates with the central nervous system progenitor cell state in many, but not all, regions of developing central nervous system. Brain Res Dev Brain Res 84:109-129.

De Jonghe P, Mersivanova I, Nelis E, Del Favero J, Martin JJ, Van Broeckhoven C, Evgrafov O, Timmerman V (2001) Further evidence that neurofilament light chain gene mutations can cause Charcot-Marie-Tooth disease type 2E. Ann Neurol 49:245-249.

Ehlers MD, Fung ET, O’Brien RJ, Huganir RL (1998) Splice variant-specific interaction of the NMDA receptor subunit NR1 with neuronal intermediate filaments. J Neurosci 18:720-730.

Eyer J, Peterson A (1994) Neurofilament-deficient axons and perikaryal aggregates in viable transgenic mice expressing a neurofilament-betagalactosidase fusion protein. Neuron 12:389-405.

Faussone-Pellegrini MS, Matini P, DeFelici M (1999) The cytoskeleton of the myenteric neurons during murine embryonic life. Anat Embryol (Berl) 199:459-469.

Fliegner KH, Kaplan MP, Wood TL, Pintar JE, Liem RK (1994) Expression of the gene for the neuronal intermediate filament protein alphainternexin coincides with the onset of neuronal differentiation in the developing rat nervous system. J Comp Neurol 342:161-173.

Gama Sosa MA, Friedrich Jr VL, DeGasperi R, Kelley K, Wen PH, Senturk E, Lazzarini RA, Elder GA (2003) Human midsized neurofilament subunit induces motor neuron disease in transgenic mice. Exp Neurol 184:408-419.

Garcia ML, Lobsiger CS, Shah SB, Deerinck TJ, Crum J, Young D, Ward CM, Crawford TO, Gotow T, Uchiyama Y, Ellisman MH, Calcutt NA, Cleveland DW (2003) NF-M is an essential target for the myelin-directed "outside-in" signaling cascade that mediates radial axonal growth. J Cell Biol 163:1011-1020.

Georgiou DM, Zidar J, Korosec M, Middleton LT, Kyriakides T, Christodoulou K (2002) A novel NF-L mutation Pro22Ser is associated with CMT2 in a large Slovenian family. Neurogenetics 4:93-96.

Giasson BI, Mushynski WE (1997) Developmentally regulated stabilization of neuronal intermediate filaments in rat cerebral cortex. Neurosci Lett 229:77-80.

Gilad GM, Gilad VH, Dahl D (1989) Expression of neurofilament immunoreactivity in developing rat cerebellum in vitro and in vivo. Neurosci Lett 96:7-12.

Griffiths G, Simons K, Warren G, Tokuyasu KT (1983) Immunoelectron microscopy using thin, frozen sections: application to studies of the intracellular transport of Semliki Forest virus spike glycoproteins. Methods Enzymol 96:466-485.

Gros-Louis F, Lariviere R, Gowing G, Laurent S, Camu W, Bouchard JP, Meininger V, Rouleau GA, Julien JP (2004) A frameshift deletion in peripherin gene associated with amyotrophic lateral sclerosis. J Biol Chem 279:45951-45956.

Heimann R, Shelanski ML, Liem RK (1985) Microtubule-associated proteins bind specifically to the $70-\mathrm{kDa}$ neurofilament protein. J Biol Chem 260:12160-12166.

Hirokawa N, Glicksman MA, Willard MB (1984) Organization of mammalian neurofilament polypeptides within the neuronal cytoskeleton. J Cell Biol 98:1523-1536.

Jacomy H, Zhu Q, Couillard-Despres S, Beaulieu JM, Julien JP (1999) Disruption of type IV intermediate filament network in mice lacking the neurofilament medium and heavy subunits. J Neurochem 73:972-984.

Jing-Ping Z, Tian QB, Sakagami H, Kondo H, Endo S, Suzuki T (2005) p55 protein is a member of PSD scaffold proteins in the rat brain and interacts with various PSD proteins. Brain Res Mol Brain Res 135:204-216.

Jordanova A, De Jonghe P, Boerkoel CF, Takashima H, De Vriendt E, Ceuterick C, Martin JJ, Butler IJ, Mancias P, Papasozomenos S, Terespolsky D, Potocki L, Brown CW, Shy M, Rita DA, Tournev I, Kremensky I, Lupski JR, Timmerman V (2003) Mutations in the neurofilament light chain gene (NEFL) cause early onset severe Charcot-Marie-Tooth disease. Brain 126:590-597.

Josephs KA, Holton JL, Rossor MN, Braendgaard H, Ozawa T, Fox NC, Petersen RC, Pearl GS, Ganguly M, Rosa P, Laursen H, Parisi JE, Waldemar G, Quinn NP, Dickson DW, Revesz T (2003) Neurofilament inclusion body disease: a new proteinopathy? Brain 126:2291-2303.

Kaplan MP, Chin SS, Fliegner KH, Liem RK (1990) $\alpha$-Internexin, a novel neuronal intermediate filament protein, precedes the low molecular weight neurofilament protein (NF-L) in the developing rat brain. J Neurosci 10:2735-2748.

Kim OJ, Ariano MA, Lazzarini RA, Levine MS, Sibley DR (2002) Neurofilament-M interacts with the $\mathrm{D}_{1}$ dopamine receptor to regulate cell surface expression and desensitization. J Neurosci 22:5920-5930.

Kong J, Tung VW, Aghajanian J, Xu Z (1998) Antagonistic roles of neurofilament subunits NF-H and NF-M against NF-L in shaping dendritic arborization in spinal motor neurons. J Cell Biol 140:1167-1176.

Lariviere RC, Julien JP (2004) Functions of intermediate filaments in neuronal development and disease. J Neurobiol 58:131-148.

Lendahl U, Zimmerman LB, McKay RD (1990) CNS stem cells express a new class of intermediate filament protein. Cell 60:585-595.

Leung CL, He CZ, Kaufmann P, Chin SS, Naini A, Liem RK, Mitsumoto H, Hays AR (2004) A pathogenic peripherin gene mutation in a patient with amyotrophic lateral sclerosis. Brain Pathol 14:290-296.

Levavasseur F, Zhu Q, Julien JP (1999) No requirement of alpha-internexin for nervous system development and for radial growth of axons. Brain Res Mol Brain Res 69:104-112.

Liberski PP, Rodgers-Johnson P, Yanagihara R, Lee JW, Kramer BS, Piccardo P, Mora CA, Gibbs Jr CJ, Gajdusek DC (1994) Ultrastructural pathology of human T-cell lymphotropic virus type I encephalomyelopathy in a white patient with adult T-cell leukemia/lymphoma. Ultrastruct Pathol 18:511-518. 
Liberski PP, Buczynski J, Yanagihara R, Mora C, Gibbs CJ, Gajdusek C, Cartier L, Verdugo A, Araya F, Castillo L (1999) Ultrastructural pathology of a Chilean case of tropical spastic paraparesis/human T-cell lymphotropic type I-associated myelopathy (TSP/HAM). Ultrastruct Pathol 23:157-162.

Liesi P, Julien JP, Vilja P, Grosveld F, Rechardt L (1986) Specific detection of neuronal cell bodies: in situ hybridization with a biotin-labeled neurofilament cDNA probe. J Histochem Cytochem 34:923-926.

Liu Q, Xie F, Siedlak SL, Nunomura A, Honda K, Moreira PI, Zhua X, Smith MA, Perry G (2004) Neurofilament proteins in neurodegenerative diseases. Cell Mol Life Sci 61:3057-3075.

Lobsiger CS, Garcia ML, Ward CM, Cleveland DW (2005) Altered axonal architecture by removal of the heavily phosphorylated neurofilament tail domains strongly slows superoxide dismutase 1 mutant-mediated ALS. Proc Natl Acad Sci USA 102:10351-10356.

McGraw TS, Mickle JP, Shaw G, Streit WJ (2002) Axonally transported peripheral signals regulate $\alpha$-internexin expression in regenerating motoneurons. J Neurosci 22:4955-4963.

Mersiyanova IV, Perepelov AV, Polyakov AV, Sitnikov VF, Dadali EL, Oparin RB, Petrin AN, Evgrafov OV (2000) A new variant of Charcot-MarieTooth disease type 2 is probably the result of a mutation in the neurofilament-light gene. Am J Hum Genet 67:37-46.

Momeni P, Cairns NJ, Perry RH, Bigio E, Gearing M, Singleton AB, Hardy J (2005) Mutation analysis of patients with neuronal intermediate filament inclusion disease (NIFID). Neurobiol Aging 27:778.e1-778.e6.

Monteiro MJ, Cleveland DW (1989) Expression of NF-L and NF-M in fibroblasts reveals coassembly of neurofilament and vimentin subunits. J Cell Biol 108:579-593.

Mosaheb S, Thorpe JR, Hashemzadeh-Bonehi L, Bigio EH, Gearing M, Cairns NJ (2005) Neuronal intranuclear inclusions are ultrastructurally and immunologically distinct from cytoplasmic inclusions of neuronal intermediate filament inclusion disease. Acta Neuropathol (Berl) 110:360-368.

Nixon RA (1982) Increased axonal proteolysis in myelin-deficient mutant mice. Science 215:999-1001.

Nixon RA, Logvinenko KB (1986) Multiple fates of newly synthesized neurofilament proteins: evidence for a stationary neurofilament network distributed nonuniformly along axons of retinal ganglion cell neurons. J Cell Biol 102:647-659.

Nixon RA, Shea TB (1992) Dynamics of neuronal intermediate filaments: a developmental perspective. Cell Motil Cytoskeleton 22:81-91.

Pachter JS, Liem RK (1984) The differential appearance of neurofilament triplet polypeptides in the developing rat optic nerve. Dev Biol 103:200-210

Pachter JS, Liem RK (1985) alpha-Internexin, a 66-kD intermediate filament-binding protein from mammalian central nervous tissues. J Cell Biol 101:1316-1322.

Parysek LM, McReynolds MA, Goldman RD, Ley CA (1991) Some neural intermediate filaments contain both peripherin and the neurofilament proteins. J Neurosci Res 30:80-91.

Perrin FE, Boisset G, Docquier M, Schaad O, Descombes P, Kato AC (2005) No widespread induction of cell death genes occurs in pure motoneurons in an ALS mouse model. Hum Mol Genet 14:3309-3320.

Perrone Capano C, Pernas-Alonso R, di Porzio U (2001) Neurofilament homeostasis and motoneurone degeneration. BioEssays 23:24-33.

Petzold A (2005) Neurofilament phosphoforms: surrogate markers for axonal injury, degeneration and loss. J Neurol Sci 233:183-198.

Portier MM, de Nechaud B, Gros F (1983) Peripherin, a new member of the intermediate filament protein family. Dev Neurosci 6:335-344.

Rao MV, Houseweart MK, Williamson TL, Crawford TO, Folmer J, Cleveland DW (1998) Neurofilament-dependent radial growth of motor axons and axonal organization of neurofilaments does not require the neurofilament heavy subunit (NF-H) or its phosphorylation. J Cell Biol 143:171-181.

Rao MV, Garcia ML, Miyazaki Y, Gotow T, Yuan A, Mattina S, Ward CM, Calcutt NA, Uchiyama Y, Nixon RA, Cleveland DW (2002a) Gene replacement in mice reveals that the heavily phosphorylated tail of neurofilament heavy subunit does not affect axonal caliber or the transit of cargoes in slow axonal transport. J Cell Biol 158:681-693.

Rao MV, Engle LJ, Mohan PS, Yuan A, Qiu D, Cataldo A, Hassinger L, Jacobsen S, Lee VM, Andreadis A, Julien JP, Bridgman PC, Nixon RA (2002b) Myosin Va binding to neurofilaments is essential for correct myosin Va distribution and transport and neurofilament density. J Cell Biol 159:279-290.

Ratnam J, Teichberg VI (2005) Neurofilament-light increases the cell surface expression of the $N$-methyl-D-aspartate receptor and prevents its ubiquitination. J Neurochem 92:878-885.

Reddy TR, Li X, Jones Y, Ellisman MH, Ching GY, Liem RK, Wong-Staal F (1998) Specific interaction of HTLV tax protein and a human type IV neuronal intermediate filament protein. Proc Natl Acad Sci USA 95:702-707.

Riederer BM, Porchet R, Marugg RA (1996) Differential expression and modification of neurofilament triplet proteins during cat cerebellar development. J Comp Neurol 364:704-717.

Sasaki T, Gotow T, Shiozaki M, Sakaue F, Saito T, Julien JP, Uchiyama Y, Hisanaga S (2006) Aggregate formation and phosphorylation of neurofilament-L Pro22 Charcot-Marie-Tooth disease mutants. Hum Mol Genet 15:943-952.

Scott D, Smith KE, O'Brien BJ, Angelides KJ (1985) Characterization of mammalian neurofilament triplet proteins. Subunit stoichiometry and morphology of native and reconstituted filaments. J Biol Chem 260:10736-10747.

Shea TB, Beermann ML (1999) Neuronal intermediate filament protein alpha-internexin facilitates axonal neurite elongation in neuroblastoma cells. Cell Motil Cytoskeleton 43:322-333.

Steinert PM, Marekov LN, Parry DA (1999) Molecular parameters of type IV alpha-internexin and type IV-type III alpha-internexin-vimentin copolymer intermediate filaments. J Biol Chem 274:1657-1666.

Stettler DD, Yamahachi H, Li W, Denk W, Gilbert CD (2006) Axons and synaptic boutons are highly dynamic in adult visual cortex. Neuron 49:877-887.

Suzuki T, Mitake S, Okumura-Noji K, Shimizu H, Tada T, Fujii T (1997) Excitable membranes and synaptic transmission: postsynaptic mechanisms. Localization of alpha-internexin in the postsynaptic density of the rat brain. Brain Res 765:74-80.

Suzuki T, Li W, Zhang JP, Tian QB, Sakagami H, Usuda N, Kondo H, Fujii T, Endo S (2005) A novel scaffold protein, TANC, possibly a rat homolog of Drosophila rolling pebbles (rols), forms a multiprotein complex with various postsynaptic density proteins. Eur J Neurosci 21:339-350.

Theiss C, Napirei M, Meller K (2005) Impairment of anterograde and retrograde neurofilament transport after anti-kinesin and anti-dynein antibody microinjection in chicken dorsal root ganglia. Eur J Cell Biol $84: 29-43$.

Tokuyasu KT (1986) Application of cryoultramicrotomy to immunocytochemistry. J Microsc 143:139-149.

Undamatla J, Szaro BG (2001) Differential expression and localization of neuronal intermediate filament proteins within newly developing neurites in dissociated cultures of Xenopus laevis embryonic spinal cord. Cell Motil Cytoskeleton 49:16-32.

Usui H, Ichikawa T, Miyazaki Y, Nagai S, Kumanishi T (1996) Isolation of cDNA clones of the rat mRNAs expressed preferentially in the prenatal stages of brain development. Brain Res Dev Brain Res 97:185-193.

Vickers JC, Chiu FC, Costa M (1992) Selective distribution of the 66-kDa neuronal intermediate filament protein in the sensory and autonomic nervous system of the guinea-pig. Brain Res 585:205-211.

Vitadello M, Denis-Donini S (1990) Expression of neurofilament proteins in granule cells of the cerebellum. Brain Res 509:47-54.

Wagner OI, Lifshitz J, Janmey PA, Linden M, McIntosh TK, Leterrier JF (2003) Mechanisms of mitochondria-neurofilament interactions. J Neurosci 23:9046-9058.

Wu E, Dickson DW, Jacobson S, Raine CS (1993) Neuroaxonal dystrophy in HTLV-1-associated myelopathy/tropical spastic paraparesis: neuropathologic and neuroimmunologic correlations. Acta Neuropathol (Berl) $86: 224-235$.

Xia CH, Roberts EA, Her LS, Liu X, Williams DS, Cleveland DW, Goldstein LS (2003) Abnormal neurofilament transport caused by targeted disruption of neuronal kinesin heavy chain KIF5A. J Cell Biol 161:55-66.

Xu Z, Cork LC, Griffin JW, Cleveland DW (1993) Increased expression of neurofilament subunit NF-L produces morphological alterations that resemble the pathology of human motor neuron disease. Cell 73:23-33.

Yoshihara T, Yamamoto M, Hattori N, Misu K, Mori K, Koike H, Sobue G (2002) Identification of novel sequence variants in the neurofilament- 
light gene in a Japanese population: analysis of Charcot-MarieTooth disease patients and normal individuals. J Peripher Nerv Syst 7:221-224.

Yuan A (2006) Neurofilament protein partnership, transport, phosphorylation and neurodegeneration. In: New research on neurofilament proteins (Arlen RK, ed). New York: Nova Science.

Yuan A, Mills RG, Bamburg JR, Bray JJ (1997) Axonal transport and distribution of cyclophilin A in chicken neurones. Brain Res 771:203-212.

Yuan A, Mills RG, Chia CP, Bray JJ (2000) Tubulin and neurofilament proteins are transported differently in axons of chicken motoneurons. Cell Mol Neurobiol 20:623-632.

Yuan A, Rao MV, Kumar A, Julien JP, Nixon RA (2003) Neurofilament transport in vivo minimally requires hetero-oligomer formation. J Neurosci 23:9452-9458.

Yuan A, Nixon RA, Rao MV (2006) Deleting the phosphorylated tail domain of the neurofilament heavy subunit does not alter neurofilament transport rate in vivo. Neurosci Lett 393:264-268.

Zhu Q, Couillard-Despres S, Julien JP (1997) Delayed maturation of regenerating myelinated axons in mice lacking neurofilaments. Exp Neurol 148:299-316.

Zuchner S, Vorgerd M, Sindern E, Schroder JM (2004) The novel neurofilament light (NEFL) mutation Glu397Lys is associated with a clinically and morphologically heterogeneous type of Charcot-Marie-Tooth neuropathy. Neuromuscul Disord 14:147-157. 